\title{
CONVERGENCE TO THE LAW OF ONE \\ PRICE WITHOUT TRADE BARRIERS \\ OR CURRENCY FLUCTUATIONS
}

\author{
David C. Parsley \\ Shang-Jin Wei
}

Working Paper 5654

\section{NATIONAL BUREAU OF ECONOMIC RESEARCH 1050 Massachusetts Avenue \\ Cambridge, MA 02138 \\ July 1996}

This paper is part of NBER's research program in International Finance and Macroeconomics. Any opinions expressed are those of the authors and not those of the National Bureau of Economic Research.

(C) 1996 by David C. Parsley and Shang-Jin Wei. All rights reserved. Short sections of text, not to exceed two paragraphs, may be quoted without explicit permission provided that full credit, including $(\mathcal{C}$ notice, is given to the source. 


\title{
CONVERGENCE TO THE LAW OF ONE PRICE WITHOUT TRADE BARRIERS OR CURRENCY FLUCTUATIONS
}

\begin{abstract}
Using a panel of 51 prices from 48 cities in the United States we provide an upper bound estimate of the rate of convergence to Purchasing Power Parity. We find convergence rates substantially higher than typically found in cross-country data. We investigate some potentially serious biases induced by i.i.d. measurement errors in the data, and find our estimates to be robust to these potential biases. We also present evidence that convergence occurs faster for larger price differences. Finally, we find that rates of convergence are slower for cities farther apart. However, our estimates suggest that distance alone can only account for a small portion of the much slower convergence rates across national borders.
\end{abstract}

David C. Parsley

Owen Graduate School of Management

Vanderbilt University

Nashville, TN 37203
Shang-Jin Wei

Kennedy School of Government

Harvard University

Cambridge, MA 02138

and NBER 


\section{Introduction}

The aim of this paper is to provide an upper bound estimate of the rate of convergence to purchasing power parity (PPP). The speed at which relative prices move toward parity is important for theories of exchange rate determination and for open-economy macro models, almost all of which employ versions of PPP. Professional wisdom regarding the rate of convergence toward PPP has run the full gamut - from fairly high, to nearly zero, and now, back to positive but slow. In markets for goods and services there is little expectation that price disparities will instantly disappear as they do, for example, in financial markets, due to both explicit and implicit barriers to the flows of goods and services. We examine convergence in a context where many of these barriers are absent in order to quantitatively assess their importance in markets less integrated.

Not long after Jacob Frenkel's seminal work (1978) which provided evidence supportive of convergence to PPP during a hyperinflation, many subsequent studies concluded a "collapse of purchasing power parities." ${ }^{1}$ In particular, these studies failed to reject the hypothesis that real exchange rates follow a random walk, which implies that any deviation from PPP is permanent. This finding undermined confidence in a wide range of open-economy macro models that assumed some version of PPP, including monetary theories of the exchange rate, and Dormbush's overshooting model.

Recent research has focused on increasing statistical power by using longer time series (Frankel 1986, Edison 1987), and on combining cross-sectional and time series features of the data (Abuaf and Jorion 1990, Frankel and Rose 1995, Papell 1996, Wei and Parsley 1995). These studies have been considerably more successful at rejecting the unit root null hypothesis. 
While these studies have found mean reversion in real exchange rates, the implied half lives of between three and seven years have been difficult to interpret.

In this study we focus exclusively on prices within the United States in order to establish a natural benchmark for comparison to international evidence. ${ }^{2}$ The use of this data set abstracts from two potentially important influences on the rate of convergence: trade barriers and exchange rate volatility. Additionally, the higher degree of factor market integration further limits departures from price parity and thus facilitates convergence. A second important feature of this study is the use of commodity level price data. Thus we implicitly control for terms of trade and other aggregation effects that can impact convergence estimates. A further benefit is that we are able to make direct comparisons of how rates of convergence depend on the degree of tradability. Finally, we explicitly examine the effects of taxes and transportation costs on estimated rates of convergence. To our knowledge, this is the first study that looks at the effect of tax rates on convergence.

Section II describes the data and its collection in more detail. Section III begins by providing some summary statistics on the price data and subsequently provides estimates of rates of convergence. After comparing rates of convergence across (and within) tradable and non-tradable groupings, we investigate other influences on our findings. A final section summarizes our main conclusions.

\section{Data}

The 51 final goods and services prices in our panel are sampled (quarterly) from 48 cities in the United States over the period 1975.1 through 1992.4. The data set includes prices of both tradable and non-tradable goods and services. The price data was assembled from publications of the American Chamber of Commerce Researchers Association, and included in the publication, Cost of Living Index (hereafter, Index). Each quarterly issue of the Index contains comparative average 
price data for a sample of urban areas, and a cost of living index computed from these data by the association. In this study we use only the raw price data.

The actual data collection is done by the local Chamber of Commerce staff or volunteers for the Chamber, and is voluntary. Explicit instructions and data forms are provided for each data collector by the association. ${ }^{3}$ Some prices are obtained by phone and usually the respondents do not know it is for a survey. Once collected, the data is sent to one of nine different regional coordinators for checking. Finally, the data is sent to Houston where it is transferred to computer and subjected to both computer and visual checks for outliers. Publication occurs approximately five and one half months after the original data are collected.

Consequently the sample of cities included in each issue of the Index varies. At the beginning of our sample period there were one hundred sixty six cities and forty four items priced. The number of cities steadily increased to two hundred ninety seven in 1992.4; however each report contains a distinct sample of cities. In an attempt to construct a balanced panel, we choose a sample of forty eight cities which appeared in roughly ninety percent of the quarterly surveys.

The goods and services sampled however are much less variable, though there have been additions to and subtraction's from the list. For this study we selected fifty one goods and services (hereafter, commodities) with three criteria in mind. First, for each commodity we wanted wide coverage in terms of availability across cities and over time. Second, we wanted variation in the degree of tradability of the commodities included in the data set. Finally, we wanted homogeneity in the definitions of the commodities over time. Some commodities did however, change during the sample period; typically as a result of a change in manufacturer packaging. This change was accounted for by assigning a missing value to the last quarter prior to the change. 
For this study, we classify the goods into tradables (41) and non-tradables (mostly services) (10), for a total of 51 goods and services. Within the tradable category, we make a further distinction between perishable goods (mostly vegetables and dairy products) and non-perishable goods. These categories were designed to facilitate the presentation of our results. While it is true that the groupings necessarily involve some subjective judgment, redesignating certain commodities into a different category would not change the basic conchusions. Appendix tables A1 and A2 provide a complete list and description of all commodities and cities included in this study. ${ }^{4}$

Briefly, our sample of (15) perishable goods includes prices for: bacon, bananas, bread, cheese, eggs, fried chicken, ground beef, lettuce, margarine, McDonalds hamburger, milk, potatoes, pizza, steak, and, whole chicken. The prices are for some standard unit, e.g., per pound. The (26) non-perishable goods are: aspirin, baby food, beer, cigarettes, coffee, com flakes, frozen com, game, jeans, liquor, man's shirt, canned orange juice, canned peaches, shampoo, shortening, soft drink, sugar, canned peas, tennis balls, tissue, canned tomatoes, toothpaste, tuna, underwear, washing powder, Wine. The (10) non-tradable goods in the sample are: appliance repair, auto maintenance, beauty salon, bowling, dentist, doctor, dry cleaning, hospital room, man's haircut, and the price to attend a first nun movie.

The tax data are combined (state, county, and local) sales tax rates collected from each local jurisdiction's taxing authority, e.g., the Departments of Revenue. The data were typically obtained by phone, though some jurisdictions provided written histories of tax rates and exemptions. For this study it was also necessary to determine whether the good was subject to a differential (including possibly exempt) tax rate since our sample includes many food and service items and the treatment of these is not uniform across jurisdictions. For our study the primary difference across jurisdictions is in the treatment of grocery items. Thus we created two tax tables with tax rates for grocery, and one 
for non-grocery items, for each city. The group we designate as perishables is composed exclusively of grocery items. Our non-perishables group also contains some non-grocery items. Finally, the nontradables group contains services for which there is generally no sales tax payable explicitly by the customer. For this reason, we exclude non-traded goods from the analysis explicitly incorporating taxes. Appendix table A3 provides some summary statistics on the tax data. For each city, the table records (a) the sales tax rates in effect in the last quarter of our sample, and the change in tax rates between (b) 1975-1984, and (c) 1984-1992, for both grocery and non-grocery items. The summary statistics at the bottom of the table indicate that there is wide variation across cities though less variation over time.

\section{Convergence}

\section{A. Basic Statistics}

Before discussing our regression results, it is useful to look at some summary statistics on the variability of price differentials and on mean absolute price differentials that are presented in Table I. In the table we compare the three groups on the basis of these two measures of the intercity price differentials over time. Our benchmark city is New Orleans. As a robustness check, we have also considered using New York as the benchmark city; this change has little effect on the conclusions we draw.

Define the (pre-tax) price difference, $Q_{i j, k t}$, as the percentage difference in price of commodity $\mathrm{k}$ at time $\mathrm{t}$ between cities $\mathrm{i}$ and $\mathrm{j}$, i.e., $Q_{i j, k t}=\ln \left(P_{i, k, t} / P_{j, k s}\right)$. The natural benchmark for $Q_{i j, k, t}$ is zero. However, given impediments to arbitrage of goods and services, the price difference at any point in time may differ from zero. In models presented in Engel and Rogers (1994), and Wei and Parsley (1995), prices in two locations may differ at any point in time, but these differences are 
bounded due to the cost of arbitrage between the two cities. The width of this band increases with transportation costs, which can be approximated by distance. This implies that both the variability of $Q_{i j, k, t}$, and the mean absolute deviation, i.e., the mean over time of $\left|\ln \left(P_{i, k, t} / P_{j, k, t}\right)\right|$, are positively related to transportation costs between cities.

From Table I we see that, of the three groups, perishables has on average, the highest variability of the inter-city price differential while services has the highest mean average price differential. The higher variability of perishables price differences could be due to seasonal variation in either the arrival of, or demand for, some of the goods in this group.

It is useful to link these indicators of the magnitude and variability of price differentials with the costs of arbitrage activities, which is what we turn to in Table II. The table presents results by group (i.e., perishables, non-perishables, and services) on the impact of distance on inter-city price differentials. Following Engel and Rogers (1994), and Wei and Parsley (1995), we approximate transportation costs by distance as measured by the "greater circle distance" between the cities. ${ }^{5}$ The results in Table II overwhelmingly support the implication of these models that transportation costs permit price differences between cities, and the size of such differences increases with arbitrage costs.

From the table, the distance between two cities is positively related to the variability of price differences for all three categories, with the effect being the strongest among tradables. The results for mean absolute price differentials is presented in Panel B. Again, the implication of the models is strongly supported. We explore a possible non-linearity in this relationship by adding a squared distance term to these specifications: the distance effect shows different convexities for different product groups but the convexity features depend on whether we examine the variability of, or mean absolute price differentials. 


\section{B. Testing for Stationarity and Estimating Rates of Convergence}

In this section we proceed in two stages. First, we test whether it is possible to reject the unit root hypothesis, and we ask whether the answer varies systematically across products. After rejecting the unit root we turn to the issue of convergence speed. At this stage the possibility of measurement error must be considered, which leads us to additional estimations prior to reporting rates of convergence. For expositional convenience, we discuss each of the three groups separately.

In our test, the null hypothesis is a (driftless) random walk. The altemative hypothesis is a zero-mean AR(1) process common to all city-pairs. All regressions reported use New Orleans as the benchmark city, i.e., we examine differences in prices in other cities relative to New Orleans. More precisely, for each commodity $(\mathrm{k})$ the basic regression specification is:

$$
\Delta Q_{i, k, t}=\beta Q_{i, k, t-1}+\sum_{m=1}^{s(k)} \gamma_{m} \Delta Q_{i, k, t-m}+\varepsilon_{i, k, t}
$$

where $Q_{i, k,}$ is the log-difference in the price of product $\mathbf{k}$ in city $\mathrm{i}$ relative to New Orleans at time $\mathrm{t}$, and, $\Delta$ is the first difference operator. The lag structure, $s(k)$, used to account for possible serial correlation in the error term, is determined on a product-by-product basis as in a univariate augmented Dickey-Fuller test.

Results of panel unit root tests for the first category (i.e., non-perishables) are summarized in Panel A of Table III. The table presents the tests on a commodity by commodity basis. Levin and Lin (1992) have shown that panel data can dramatically increase the power of the unit root test, and that in contrast to univariate case, the test statistic in a panel context is asymptotically normal. In all cases, the point estimate of $\beta$ is negative. According to Levin and Lin, the critical values for $\mathrm{t}=50$ and $\mathrm{N}=50$ (approximately our panel size) at the $1 \%, 5 \%$ and $10 \%$ 
levels are $-2.38,-1.71$, and -1.35 . Using these critical values, we reject the unit root for twenty two of the twenty six products (or $85 \%$ ) at the $10 \%$ level, of which twenty are rejected at the $5 \%$ level.

In Panel B of Table III, we examine the (15) perishables, and (10) services. For perishables, we can reject the random walk null at the ten percent level for an overwhelming majority ( $80 \%$, or twelve) of the commodities. In fact, we can reject it at the $1 \%$ level for ten of the fifteen goods. Even for our final group of mostly services, we can reject the null at the $10 \%$ level in half of the cases; it can be rejected at the $1 \%$ level in four of the five cases. This implies that price differences for many of the items that would be called "non-tradable" in an international context are disciplined to not wander away from zero indefinitely.

Thus, the bulk of the evidence rejects the random walk null hypothesis in favor of a zeromean stationary process for all three categories. Does this imply that the distinction between tradables and non-tradables is unimportant within a given country? Not necessarily, since so far we have not addressed the issue of the speed of convergence. Under the assumption that the $Q_{i, k, t}$ process is a zero-mean $\mathrm{AR}(1)$ process, the rate of convergence is positively related to the absolute size of the estimated coefficient $\beta^{6}$ In Figure 1, we plot the empirical density functions of the estimated $\operatorname{AR}(1)$ coefficients for the three categories based on the estimates in Table III. As can be seen, the estimated coefficients for the service items tend to be smaller in absolute magnitude than both the perishables and the non-perishables groups. That is, on average, the deviation from price parity tends to last longer for services.

[Figure 1 approximately here]

A further way to examine differences among the three groups is to focus on the median convergence rate for each group. That is, for each group, we calculate the implied half-life for the product whose AR(1) coefficient is the median value in the group. ${ }^{7}$ The medians are corn 
flakes $(-0.123)$, fried chicken $(-0.157)$, and beauty salon visit $(-0.044)$, for non-perishables, perishables, and services, respectively. These coefficient estimates imply half-lives for deviations from parity of approximately five quarters for non-perishables, four quarters for perishables, and fifteen quarters for services. ${ }^{8}$ Thus in fact, the median convergence rate is substantially lower for the services category than for either of the tradable counterparts. In a broader context, both tradable categories converge substantially faster than rates estimated in an international context (typically with a half-life of three to five years, see Frankel and Rose, 1995, for CPI-based real exchange rates, and Wei and Parsley, 1995, for tradable sector price indices).

\section{City specific effects}

So far, the only alternative to a random walk null that we have entertained is a meanzero AR(1) process. We may also want to consider non-zero city-specific means. This is to allow the sale prices of the products to reflect the cost of local non-traded components (e.g., extra store security guards in a more crime-prone city). Additionally, we may want to control for possible seasonal effects. Specifically, we augment the basic specification in Table III by allowing city and quarter dummies, i.e.,

$$
\Delta Q_{i, k, t}=\beta Q_{i, k t-1}+\sum_{m=1}^{s(k)} \gamma_{m} \Delta Q_{i, k, t-1}+\sum \text { city and quarter dummies }+\varepsilon_{i, k, t}
$$

The results are reported in Table IV. We also perform an F-test to see if the city dummies are jointly significant. It turns out that for about sixty percent of the time, the city dummies are jointly significant if we use a $10 \%$ critical value. As demonstrated by Levin and Lin (1992), the critical values to reject the unit root null increase dramatically in a fixed effects regression relative to a uniform intercept case, and a comparison of their figures 4 and 9 indicates that the power to reject the null also declines. According to their Table V, the critical 
values at the $1 \%, 5 \%$ and $10 \%$ levels for $\mathrm{T}=50$ and $\mathrm{N}=25$ (approximately our panel size after allowing for lagged dependent variables) are $-8.25,-7.71$ and -7.39 , respectively. Based on these critical values, we can reject the unit root null far less frequently than for the case of a zero-mean $\mathrm{AR}(1)$ process as the alternative: $53 \%$ for perishables, $31 \%$ for non-perishables, and only $10 \%$ for services. This result echoes that in Frankel and Rose (1995) who, using a panel of real exchange rates from IMF member countries, also find it hard to reject the unit root null when fixed effects are allowed.

In an effort to increase the power of the statistical tests we pooled the data and repeated the estimation. Appendix Table A4 summarizes our results. In the table we report two specifications, which differ only in what dummies are included in the regression. In the first regression we include only city-pair dummies, and in the second regression we include both citypair and product dummies. For these regressions the critical values in Levin and Lin (1992) for $\mathrm{T}=50$ and $\mathrm{N}=300$ (the largest cross-section dimensions they report) are -23.03 , and -22.72 , for the $5 \%$, and $10 \%$ levels respectively. Using these critical values, we can reject the unit root in regressions with individual specific intercepts only for perishables. Thus the inclusion of individual specific fixed effects greatly diminishes our ability to reject the unit root hypothesis. Note that for non-perishables and services, the point estimates obtained from the pooled estimation are broadly similar to those reported in Table III, though for perishables the estimate of convergence is somewhat faster. ${ }^{9}$

In an international context various authors have found results sensitive to the choice of benchmark currency (e.g., Frenkel 1981, and Fisher and Park 1991). We repeated the panel augmented Dickey-Fuller tests using New York as an alternate benchmark city. Appendix Table 
A5 summarizes these results. Our ability to reject the null is virtually unaffected by the choice of benchmark city. Thus in what follows we use the New Orleans benchmark exclusively.

\section{Tax adjustment}

As noted in Caves, Frankel and Jones (1995), tariffs and transportation costs create a band within which the real exchange rate can fluctuate. Moreover, time variation in taxes or transportation costs suggests the band itself would shift. There is little guidance in the literature however, concerning whether PPP should hold on a pre-tax, or tax adjusted basis. One might conjecture that consumers care about post-tax prices while producers respond to pre-tax prices. That is, a sufficiently large post-sales tax price differential between two cities would induce consumers to arbitrage the difference. Alternatively if pre-sales tax prices between two cities diverge too far, producers would respond and arbitrage this difference.

Define $R_{\mathrm{i}, \mathrm{k} s}$ be the tax adjusted price difference for product $\mathrm{k}$ at time $\mathrm{t}$ between city $\mathrm{i}$ and New Orleans, i.e., $R_{i, k, t}=\log \frac{P_{i, k, t}\left(1+t_{i, k, t}\right)}{P_{j, k, t}\left(1+t_{j, k, t}\right)}$, where $\mathrm{t}$ is the tax rate and $\mathrm{j}=$ New Orleans. Also, define $Z_{i, k, t}$ to be either $Q_{i, k, t}$, or $R_{i, k, t}$, depending on which one is smaller in absolute value. Thus $Z_{i, k,}$ is the minimum price difference at each point in time.

In Tables $\mathrm{V}$ and VI, we repeat the tests for these (minimum) price differences. Since sales taxes generally do not apply to the services in our study, we restrict the discussion to the two tradable groups. From the tables we see that both the estimates, and our ability to reject the null hypothesis, are virtually unaffected. What these tables suggest is that explicit sales taxes have a minimal influence on the time series properties of deviations from price parity. Thus, in the remaining analysis we focus on the non-tax adjusted price differentials. 


\section{E. Measurement Errors}

The convergence rates reported earlier assume no measurement error in the data. If, however, the price data are collected with measurement error, the estimates could be affected. To see this, suppose the true process is given by:

(2) $Q_{t}^{*}=\beta Q_{t-t}^{*}+\varepsilon_{t}$,

where $Q_{t}^{*}$, the true price, is unobservable. We actually observe $Q_{t}=Q_{t}^{*}+u_{t}$, where $u_{t}$ is a zeromean, serially uncorrelated measurement error. This implies that $Q_{t}=\beta Q_{t-1}+\varepsilon_{t}+u_{t}-\beta u_{t-1}$, which is almost an $\operatorname{ARMA}(1,1)$ process.

We attempt to gauge the impact of the possible measurement errors using two approaches: (1) a restricted $\operatorname{ARMA}(1,1)$ specification, and (2), an instrumental variable approach. In both approaches, we reduce the dimensionality of the problem by choosing the three products which bracket the median from each of the three categories ${ }^{10}$. We also restrict our sample to the ten cities (in addition to New Orleans) with the fewest missing observations ${ }^{11}$.

The first column of Table VII reports a simple AR(1) estimation. In the second column, we estimate an $\operatorname{ARMA}(1,1)$, in which the moving average coefficient is restricted to be the minus the autoregressive coefficient $(\theta=-\beta)$. This restriction approximates that implied by the assumption of an ii.d. measurement error. As one can see, the autoregressive coefficients in the restricted $\operatorname{ARMA}(1,1)$ are almost always larger than those in the straight $\operatorname{AR}(1)$ regressions. Hence a straightforward AR(1) regression, ignoring possible measurement error, exaggerates rates of convergence. Column 3 of Table VII presents the results of unrestricted ARMA(1,1) regressions. Comparing unrestricted and restricted $\operatorname{ARMA}(1,1)$ regressions, the coefficient restrictions are rejected in all cases. ${ }^{12}$ 
Our second method of accounting for possible measurement errors is to employ an instrumental variable approach. Specifically, we use $Q_{t-3}$ as an instrument for $Q_{t-1}$. According to our assumptions, $Q_{t-3}$ is clearly correlated with $Q_{t-1}$, yet uncorrelated with the error terms in the basic AR(1) regressions. The IV-estimation results are reported as the last columm of Table VII. There are two noteworthy features from this column. First, the coefficient estimates on $Q_{t-1}$ are higher than the corresponding $\operatorname{AR}(1)$ estimates, implying that the rates of convergence for all products are somewhat slower after accounting for possible measurement errors. And second, consistent with our earlier results, tradable goods generally converge to the law of one price faster than services. Using the IV estimates in Column 4, the half lives for the median products become 4.5 for non-perishables (com flakes), 3.5 quarters for perishables (fried chicken), and 10.5 for services (Beauty salon visit). These half lives correspond very closely to those reported earlier $(5,4$, and 15 , respectively), suggesting our estimates derived from augmented Dickey-Fuller specifications also approximately address the measurement errors issue.

\section{F. Non-linearities in the rate of convergence}

We wish to know whether convergence is non-linear in the initial price difference, as found by e.g., Wei and Parsley (1995). In particular, convergence may occur faster if the imitial price difference is wider. For ease of exposition, we pool the data, and report results for each of our three groups. To examine formally whether there is a non-linear pattern in the rate of convergence, we add a term of the initial deviation squared to the regression, and add product dummies. To be precise, the specification for each group is,

$$
\Delta Q_{i j, k, t}=\beta_{0} Q_{i j, k, t-1}+\gamma Q_{i j, k, t-1}^{2}+\sum_{m=1}^{16} \beta_{m} \Delta Q_{i j, k, t-m}+\text { dummies }+\varepsilon_{i j, k,}
$$


The quarterly decay rate now becomes: $\beta_{0}+2 \gamma Q_{i j, k, t-1}$. The estimation results are reported in

Table VIII. In the table we report four specifications depending on the structure of lagged dependent variables and additional fixed effects. As is clear from the table, the conclusion does not depend crucially on the specification. In particular, the squared price difference is statistically significant for all three product/service categories, and for virtually all specifications. Thus, there is strong evidence that the rate of convergence depends on the initial price differential, i.e., convergence occurs faster for larger price differences.

Results in Table II imply that distance is a factor in explaining inter-city price differential variability, i.e., price differentials are more variable for cities farther apart. We now ask whether an effect exists on rates of convergence. In Table IX we augment the basic specification (equation 1) with two more terms. The first is log distance and the second is an interaction term between $\log$ distance and the initial price differential,

$$
\Delta Q_{i j, k, t}=\theta \ln (\text { distance })+\beta_{0} Q_{i j, k,-1}+\gamma Q_{i j, k, t-1} \ln (\text { distance })+\sum_{m=1}^{16} \beta_{m} \Delta Q_{i j, k, t-m}+\text { dummies }+\varepsilon_{i j, k s}
$$

Results in the table provide evidence that convergence rates are slower for cities farther apart. The implied half life now depends on the distance between the cities in question and on the imitial price difference. An approximation can be obtained however by using the average distance between cities within the United States (856 miles using New Orleans as the benchmark city) and the estimates obtained from Tables III. Using the results in Column 4, the (approximate) half lives for nonperishables, perishables, and services are 6,3 , and 14 quarters. ${ }^{13}$

We are now in a position to ask how the convergence rates estimated in this paper compare to existing estimates obtained from cross-country data. That is, our lower estimated convergence rates may simply reflect the fact that cities within the United States are closer to one another than "typical" international city pairs. Indeed, the average distance between the 
OECD sample in Wei and Parsley (1995) is 3285 miles (using the United States as a benchmark) as compared to 856 miles for this sample. According to the estimates in Column 4 of Table LX, if distance were the only factor differentiating cities within the United States and OECD cities, the average half lives among OECD countries would be (approximately) four to seven quarters for tradables. However, estimates in Wei and Parsley (1995) for tradable sector price indices are closer to four years! $!^{14}$ Similarly, if distance were the only factor, then price differences for services that would be classified "non-tradable" internationally, would have a half life of about 18 quarters. Thus we conclude that distance explains only a small part of the difference between domestic and international estimates of convergence.

\section{Conclusion}

To summarize, there are a few noteworthy observations. First, tradable goods (perishable and non-perishable categories) converge very fast to price parity. The half life of the price gap for tradable goods is roughly four to five quarters (fried chicken and com flakes), and fifteen quarters for services (beauty salon visit). Convergence rates for both tradable categories (perishables and nonperishables) are much faster than those found in cross-country data; indeed, the convergence rate for our least tradable category is on par with convergence rates found in studies examining intemational tradable goods. These conclusions are not affected by the presence of tax differentials or by possible measurement errors in the data. Additionally, we present evidence of non-linearities in the rate of convergence. In particular, convergence occurs faster for larger initial price differences, and far away locations exhibit slower convergence. However using these estimates we find that transport costs account for only a small portion of the much slower convergence rates found in cross-country data. 


\section{ENDNOTES}

1. See the excellent survey in Froot and Rogoff 1996

2. Earlier studies examining disaggregated prices include Richardson (1978), who finds that Canadian and United States prices are only weakly related, and Rogers and Jenkins (1994), who are able to reject the unit root null in fewer than one-sixth of the 54 disaggregated products they study. While these findings are discouraging, there is reason to suspect the failures are due to the notoriously low power of common unit root tests. Recent work by Levin and Lin (1992) demonstrates that statistical power increases rapidly in a panel setting.

3. According to phone conversations with the person now in charge of final data checking for ACCRA, the reported prices were obtained as an average over a small number of sellers in the city (generally $>3$, and, since $1982,>5 \&<10$ sellers), on the Thursday, Friday, or Saturday of the first week of each quarter.

4. Our data set will be available for one year following publication. Requests should include a 3.5 inch IBM formatted (1.44MB) diskette and a self-addressed mailer.

5. See The American Practical Navigator, 1977.

6. The interpretation that follows is complicated by the possible presence of measurement errors. We return to this issue in more detail below. For now, we assume there is no measurement error in order to obtain a suggestive characterization of convergence rates across groups.

7. In the case of two medians, we pick the one with a smaller coefficient in absolute value.

8. The implied half-life $=\ln (0.5) / \ln (\beta)$.

9. On the other hand, the assumption the AR(1) coefficient is the same across products within a group, which we impose here, can also be rejected.

10. That is, in the case of a single median, we choose the median, and one product above and below the median, in terms of their rate of convergence as in Table 3 . When there are two medians, we choose the product with the next smallest coefficient estimate in absolute value as the third product.

11. Missing values were interpolated these the average of the values just prior and following the missing observations. Some experiments with other interpolation methods, e.g., by choosing the value just prior to the missing observation, did not affect our conclusions. See Table VII for a list of the ten cities included in the estimations.

12. Let $\mathrm{L}_{u}$ and $\mathrm{L}_{\mathrm{r}}$ be the $\log$ likelihood values for the unrestricted and restricted ARMA regressions, respectively. Then, $2\left(L_{u}-L_{r}\right)$ has a $\chi^{2}$ distribution with a degree of freedom of $\mathrm{N}-1$, where $\mathrm{N}$ is the number of observations. The five percent critical value is approximately 101.9 for all products

13. The half life was calculated as $\ln (0.5) /(\ln (1-\beta)+\gamma \ln ($ distance $))$. This approximation also ignores a possible drift term in the time series representation of the price differential. The approximation yields an estimate of the rate of convergence that is slightly slower than the true one when the drift term is small.

14. The estimates in Wei and Parsley (95) are in line with other cross-country evidence. See, e.g., Frankel (86), Edison (87), who obtain estimates using extremely long time-series, or more recently, Frankel and Rose (95). The estimates in Papell (95) imply even slower convergence. 


\section{REFERENCES}

American Chamber of Commerce Researchers Association, Intercity Cost of Living Index, Quarterly Reports 1975-1992.

Abuaf, Niso, and Philippe Jorion, "Purchasing Power Parity in the Long Run," Journal of Finance, XLV (1990), 157-74.

Caves, Richard, Jeffrey Frankel, and Ronald Jones, World Trade and Payments: An Introduction, 6th edition, Harper Collins, 1993.

Dombusch, Rudiger, "Expectations and Exchange Rate Dynamics," Journal of Political Economy, LXXXIV (1993), 1061-76.

Edison, Hali, "Purchasing Power Parity in the Long Run: A Test of the Dollar/Pound Exchange Rate (1890-78)," Journal of Money, Credit, and Banking, XIX (1987), 376-87.

Engel, Charles, and John Rogers, "How Wide is the Border?," NBER Working Paper No. 4829, 1994.

Fisher, Eric O., and Joon Y. Park, "Testing Purchasing Power Parity Under the Null Hypothesis of Cointegration," Economic Journal, CI (1991), 1476-84.

Frankel, Jeffrey, "International Capital Mobility and Crowding-out in the U.S. Economy: Imperfect Integration of Financial Markets or of Goods Markets?," in How Open is the U.S. Economy, Ruth Hafer, ed., Lexington, Mass: Lexington, 1986, 33-74.

Frankel, Jeffrey, and Andrew Rose, "Mean Reversion Within and Between Countries: A Panel Study of Purchasing Power Parity," NBER Working Paper No. 5006, 1995.

Frenkel, Jacob, "Purchasing Power Parity: Doctrinal perspective an evidence from the 1920 s," Journal of International Economics, VIII (1978), 169-91.

Frenkel, Jacob, "Flexible Exchange Rates, Prices and the Role of News: Lessons from the 1970s," Journal of Political Economy, LIX (1981), 665-705. 
Froot, Kenneth, Michael Kim, and Kenneth Rogoff, "The Law of One Price Over 700 Years," NBER Working Paper No. 5132, 1995.

Froot, Kenneth, and Kenneth Rogoff, "Perspectives on PPP and Long-Run Real Exchange Rates," Handbook of International Economics, volume 3, Gene M. Grossman, and Kenneth Rogoff, eds. (Amsterdam: North-Holland, 1995), 1647-1729.

Krugman, Paul, and Maurice Obstfeld, "International Economics: Theory and Practice, 3rd edition, Harper Collins, 1994

Levin, Andrew, and Chien-Fu Lin, 'Unit Root Tests in Panel Data: Asymptotic and Finite-sample Properties," manuscript, University of California, San Diego, 1992.

Lothian, James, and Mark Taylor, "Real Exchange Rate Behavior: The Recent Float From the Perspective of the Past Two Centuries," Journal of Political Economy, CIV (1996), 488-541.

Papell, David, "Searching for Stationarity: Purchasing Power Parity Under the Current Float," manuscript, University of Houston, 1996.

Richardson, J. David, "Some Empirical Evidence on Commodity Arbitrage and the Law of One Price," Journal of International Economics, VIII (1978), 341-51.

Rogers, John, and Michael Jenkins, "Haircuts or Hysteresis? Sources of Movements in Real Exchange Rates," Journal of International Economics, Vol. XXXVII (1995), 339-60.

The American Practical Navigator, volume 1: Washington, U.S. Defense Mapping Agency, 1977.

Wei, Shang-Jin, and David Parsley, "Purchasing Power Dis-Parity During the Floating Rate Period: Exchange Rate Volatility, Trade Barriers, and Other Culprits," NBER Working Paper No. 5032, (revised) April, 1995. 
Variability of Price Differential

\section{Mean Standard Deviation Observations}

Perishables

.058

705

Non-Perishables

.046

1222

Services

.049

470

Mean Absolute Price Differential

Perishables

.144

.066

705

Non-Perishables

.125

.052

1222

Services

.156

.082

470

Notes: Price differential variability is defined as the standard deviation over time of the percentage price difference $\left(Q_{i j, k, t}=\ln \left(P_{i, k, t} / P_{j, k, t}\right)\right)$. Mean absolute price differential is defined as the mean absolute deviation of $\log$ prices between cities, i.e., the mean over time of: $\left|\ln \left(P_{i, k, s} / P_{j, k, t}\right)\right|$. Where $P_{i, k, t}$ is the price of good $\mathrm{k}$ in city $\mathrm{i}$ at time $\mathrm{t}$. For these calculations city $i$ is New Orleans.

The three commodity groupings are:

Perishables

Bacon, Bananas, Bread, Cheese, Eggs, Ground Beef, Lettuce, Margarine, Milk, Potatoes, Steak, Whole Chicken, Fried Chicken, McDonalds, Pizza.

\section{Non-Perishables}

Aspirin, Baby food, Beer, Cigarettes, Coffee, Corn Flakes, Frozen Corn, Game, Jeans, Liquor, Man's Shirt, Canned Orange juice, Canned Peaches, Shampoo, Shortening, Soft

Drink, Sugar, Canned Peas, Tennis balls, Tissue, Canned Tomatoes, Toothpaste, Canned Tuna, Underwear, Washing Powder, Wine.

\section{Services}

Appliance Repair, Auto Maintenance, Beauty Salon, Bowling, Dentist, Doctor, Dry Cleaning, Hospital Room, Man's Haircut, Movie. 


\section{TABLE II: SHIPPING COSTS AND INTER-CITY PRICE DIFFERENTIALS:}

Panel A: Variability of Price Differential

\begin{tabular}{|c|c|c|c|c|c|c|}
\hline \multirow[b]{2}{*}{ Regression Number: } & \multicolumn{2}{|c|}{ Perishables } & \multicolumn{2}{|c|}{ Non-Perishables } & \multicolumn{2}{|c|}{ Services } \\
\hline & 1 & 2 & 3 & 4 & 5 & 6 \\
\hline Ln Distance & $\begin{array}{r}0.011 \\
(0.002)\end{array}$ & $\begin{array}{r}-0.087 \\
(0.022)\end{array}$ & $\begin{array}{r}0.018 \\
(0.001)\end{array}$ & $\begin{array}{r}0.038 \\
(0.002)\end{array}$ & $\begin{array}{r}0.004 \\
(0.003)\end{array}$ & $\begin{array}{r}-0.062 \\
(0.039)\end{array}$ \\
\hline Ln Distance Squared & & $\begin{array}{r}0.008 \\
(0.002)\end{array}$ & & $\begin{array}{r}-0.003 \\
(0.0003)\end{array}$ & & $\begin{array}{r}0.005 \\
(0.003)\end{array}$ \\
\hline Product dummies & yes & yes & yes & yes & yes & yes \\
\hline $\bar{R}^{2}$ & .72 & .73 & .45 & .49 & .20 & 21 \\
\hline Std. Error of Regression & .0308 & .0304 & .0341 & .0330 & .0436 & .0435 \\
\hline Number of Observations & 705 & 705 & 1222 & 1222 & 470 & 470 \\
\hline
\end{tabular}

Panel B: Mean Absolute Price Differential

\begin{tabular}{|c|c|c|c|c|c|c|}
\hline \multirow[b]{2}{*}{ Regression Number } & \multicolumn{2}{|c|}{ Perishables } & \multicolumn{2}{|c|}{ Non-Perishables } & \multicolumn{2}{|c|}{ Services } \\
\hline & 1 & 2 & 3 & 4 & 5 & 6 \\
\hline Ln Distance & $\begin{array}{r}0.019 \\
(0.0002)\end{array}$ & $\begin{array}{r}0.030 \\
(0.003)\end{array}$ & $\begin{array}{r}0.022 \\
(0.0004)\end{array}$ & $\begin{array}{r}0.019 \\
(0.005)\end{array}$ & $\begin{array}{r}0.021 \\
(0.006)\end{array}$ & $\begin{array}{r}-0.336 \\
(0.068)\end{array}$ \\
\hline Ln Distance Squared & & $\begin{array}{r}-0.002 \\
(0.0004)\end{array}$ & & $\begin{array}{r}0.0004 \\
(0.0007)\end{array}$ & & $\begin{array}{r}0.029 \\
(0.006)\end{array}$ \\
\hline Product dummies & yes & yes & yes & yes & yes & yes \\
\hline $\bar{R}^{2}$ & -.01 & .01 & .03 & .03 & .10 & .15 \\
\hline Std. Error of Regression & .0526 & .0523 & .0649 & .0649 & .0771 & .0750 \\
\hline Number of Observations & 705 & 705 & 1222 & 1222 & 470 & 470 \\
\hline
\end{tabular}

Notes: "Ln" refers to the natural log. In Panel A, columns 1, 3, and 5, the regression run was: $s . d .\left(Q_{i j, k, t}\right)=\beta \ln ($ distance $)+$ dummies, and in columns 2,4 , and 6 , the regression run was: $s . d .\left(Q_{i j, k, t}\right)=\beta_{1} \ln ($ distance $)+\beta_{2} \ln \left(\right.$ distance $\left.^{2}\right)+$ dummies, where $\quad s . d .\left(Q_{i j, k, t}\right)=$ the standard deviation over time of $\ln \left(P_{i, k, t} / P_{j, k, t}\right)$. In Panel B, the dependent variable is the mean over time of: $\left|\ln \left(P_{i, k, t} / P_{j, k, t}\right)\right|$, i.e., the mean absolute deviation of $\log$ prices between cities. Standard errors in parentheses. New Orleans is defined as the benchmark city. 


\begin{tabular}{|c|c|c|c|c|c|c|c|}
\hline \multicolumn{8}{|c|}{ Panel A: Non-Perishables } \\
\hline Good & Beta & \# lags & $\#$ obs & Good & Beta & \# lags & \#obs \\
\hline Asprin & $\begin{array}{l}-0.259 * \\
(0.056)\end{array}$ & 15 & 503 & Shampoo & $\begin{array}{l}-0.367^{*} \\
(0.085)\end{array}$ & 16 & 465 \\
\hline Baby food & $\begin{array}{l}-0.057^{* * *} \\
(0.035)\end{array}$ & * 16 & 474 & Shortening & $\begin{array}{l}-0.141^{*} \\
(0.046)\end{array}$ & 16 & 474 \\
\hline Beer & $\begin{array}{l}-0.077^{*} \\
(0.028)\end{array}$ & 13 & 585 & Soft Drink & $\begin{array}{l}-0.116^{*} \\
(0.038)\end{array}$ & 12 & 639 \\
\hline Cigarettes & $\begin{array}{l}-0.045^{* *} \\
(0.023)\end{array}$ & 16 & 474 & Sugar & $\begin{array}{l}-0.147^{*} \\
(0.036)\end{array}$ & 13 & 583 \\
\hline Coffee & $\begin{array}{l}-0.036 \\
(0.071)\end{array}$ & 14 & 258 & Canned Peas & $\begin{array}{l}-0.192^{* *} \\
(0.109)\end{array}$ & 15 & 206 \\
\hline Com Flakes & $\begin{array}{l}-0.123^{* *} \\
(0.066)\end{array}$ & 16 & 463 & Tennis Balls & $\begin{array}{l}-0.207^{*} \\
(0.067)\end{array}$ & 16 & 465 \\
\hline Frozen Com & $\begin{array}{l}-0.379 * \\
(0.096)\end{array}$ & 16 & 321 & Tissue & $\begin{array}{l}-0.063 \\
(0.047)\end{array}$ & 16 & 474 \\
\hline Game & $\begin{array}{l}-0.067^{* *} \\
(0.036)\end{array}$ & 15 & 503 & Canned Tomatoes & $\begin{array}{l}-0.141^{* *} \\
(0.082)\end{array}$ & 13 & 242 \\
\hline Jeans & $\begin{array}{l}-0.166^{*} \\
(0.063)\end{array}$ & 13 & 585 & Toothpaste & $\begin{array}{l}-0.037 \\
(0.074)\end{array}$ & 15 & 503 \\
\hline Liquor & $\begin{array}{l}-0.001 \\
(0.026)\end{array}$ & 16 & 163 & Canned Tuna & $\begin{array}{l}-0.192^{*} \\
(0.051)\end{array}$ & 15 & 502 \\
\hline Man's Shirt & $\begin{array}{l}-0.228^{*} \\
(0.055)\end{array}$ & 15 & 503 & Underwear & $\begin{array}{l}-0.058^{* * *} \\
(0.039)\end{array}$ & 16 & 465 \\
\hline Orange Juice & $\begin{array}{l}-0.319^{*} \\
(0.058)\end{array}$ & 14 & 212 & Washing Powder & $\begin{array}{l}-0.104^{* *} \\
(0.060)\end{array}$ & 16 & 182 \\
\hline Canned Peaches & $\begin{array}{l}-0.136 * \\
(0.034)\end{array}$ & 14 & 233 & Wine & $\begin{array}{l}-0.100^{*} \\
(0.025)\end{array}$ & 16 & 465 \\
\hline
\end{tabular}

Notes: Standard errors are in parentheses, and '*', '**', ‘***', denote significant at the $1 \%, 5 \%$, and $10 \%$ levels. For each good, the regression run was:

$\Delta Q_{i j, k,}=\beta Q_{i j, k, t-1}+\sum_{m=1}^{s(k)} \gamma_{m} \Delta Q_{i j, k,-m}+\varepsilon_{i j, k, t}$, where, $Q_{i j, k, t}$, is defined as the percentage difference in price of commodity $\mathrm{k}$ at time $\mathrm{t}$ between cities $\mathrm{i}$ and $\mathrm{j}$, i.e., $Q_{i j, k, t}=\ln \left(P_{i, k, t} / P_{j, k, t}\right) . \quad s(k)$ is chosen as the highest significant lag from a preliminary regression including 16 lags. New Orleans is defined as the benchmark city. 


\begin{tabular}{|c|c|c|c|c|c|c|c|}
\hline Good & Beta & \# lags & $\# o b s$ & Good & Beta \#l & lags & \#obs \\
\hline \multicolumn{8}{|l|}{ Perishables: } \\
\hline Bacon & $\begin{array}{l}-0.207^{*} \\
(0.040)\end{array}$ & 16 & 511 & McDonalds & $\begin{array}{l}-0.106^{* *} \\
(0.047)\end{array}$ & 16 & 465 \\
\hline Bananas & $\begin{array}{l}-0.427^{*} \\
(0.085)\end{array}$ & 16 & 510 & Pizza & $\begin{array}{l}-0.166^{*} \\
(0.030)\end{array}$ & 15 & 503 \\
\hline Bread & $\begin{array}{l}-0.194^{*} \\
(0.027)\end{array}$ & 10 & 1358 & Services: & & & \\
\hline Cheese & $\begin{array}{l}-0.064^{* * *} \\
(0.039)\end{array}$ & 14 & 541 & Appliance repair & $\begin{array}{l}-0.045^{*} \\
(0.023)\end{array}$ & 10 & 743 \\
\hline Eggs & $\begin{array}{l}0.117^{*} \\
(0.047)\end{array}$ & 16 & 474 & Auto Maintenance & $\begin{array}{l}-0.015 \\
(0.056)\end{array}$ & 16 & 465 \\
\hline Ground Beef & $\begin{array}{l}-0.232^{*} \\
(0.054)\end{array}$ & 12 & 688 & Beauty Salon & $\begin{array}{l}-0.044^{* * *} \\
(0.035)\end{array}$ & * 14 & 543 \\
\hline Lettuce & $\begin{array}{l}-0.251^{*} \\
(0.076)\end{array}$ & 15 & 512 & Bowling & $\begin{array}{l}-0.082 * \\
(0.028)\end{array}$ & 15 & 512 \\
\hline Margarine & $\begin{array}{l}0.010 \\
(0.045)\end{array}$ & 16 & 467 & Dentist & $\begin{array}{l}-0.015 \\
(0.023)\end{array}$ & 16 & 430 \\
\hline Milk & $\begin{array}{l}-0.109^{*} \\
(0.023)\end{array}$ & 13 & 594 & Doctor & $\begin{array}{l}-0.093 * \\
(0.056)\end{array}$ & 16 & 468 \\
\hline Potatoes & $\begin{array}{l}-0.050^{*} \\
(0.061)\end{array}$ & 15 & 579 & Dry Cleaning & $\begin{array}{l}0.006 \\
(0.035)\end{array}$ & 16 & 474 \\
\hline Steak & $\begin{array}{l}-0.018^{*} \\
(0.041)\end{array}$ & 16 & 474 & Hospital Room & $\begin{array}{l}-0.003 \\
(0.056)\end{array}$ & 13 & 594 \\
\hline Whole Chicken & $\begin{array}{l}-0.175^{*} \\
(0.022)\end{array}$ & 10 & 1732 & Man's Haircut & $\begin{array}{l}-0.017 \\
(0.035)\end{array}$ & 16 & 468 \\
\hline Fried Chicken & $\begin{array}{l}-0.157^{*} \\
(0.047)\end{array}$ & 16 & 465 & Movie & $\begin{array}{l}-0.117^{*} \\
(0.028)\end{array}$ & 13 & 321 \\
\hline
\end{tabular}

Notes: Standard errors are in parentheses, and '*', ‘**', ‘***', denote significant at the 1\%, 5\%, and $10 \%$ levels. For each good, the regression run was:

$\Delta Q_{i j, k, t}=\beta Q_{i j, k, t-1}+\sum_{m=1}^{s(k)} \gamma_{m} \Delta Q_{i j, k, t-m}+\varepsilon_{i j, k, t}$, where, $Q_{i j, k, t}$, is defined as the percentage difference in price of commodity $\mathrm{k}$ at time $\mathrm{t}$ between cities $\mathrm{i}$ and $\mathrm{j}$, i.e., $Q_{i j, k, t}=\ln \left(P_{i, k, t} / P_{j, k, t}\right)$. $s(k)$ is chosen as the highest significant lag from a preliminary regression including 16 lags. New Orleans is defined as the benchmark city. 
TABLE IV: PANEL UNIT ROOT TESTS: with seasonal and individual specific fixed effects

Panel A: Non-Perishables

\begin{tabular}{|c|c|c|c|c|c|c|c|}
\hline Good & Beta & F-test & signif. & Good & Beta & F-test & signif. \\
\hline Asprin & $\begin{array}{l}-0.661 \\
(0.101)\end{array}$ & 0.93 & 0.599 & Shampoo & $\begin{array}{l}-1.595^{* * *} \\
(0.214)\end{array}$ & 1.30 & 0.101 \\
\hline Baby food & $\begin{array}{l}-1.142^{*} \\
(0.119)\end{array}$ & 2.86 & 0.001 & Shortening & $\begin{array}{l}-0.677 \\
(0.120)\end{array}$ & 1.62 & 0.009 \\
\hline Beer & $\begin{array}{l}-0.713 * * * \\
(0.095)\end{array}$ & 1.57 & 0.012 & Soft Drink & $\begin{array}{l}-0.458 \\
(0.102)\end{array}$ & 1.51 & 0.019 \\
\hline Cigarettes & $\begin{array}{l}-0.831^{* *} \\
(0.104)\end{array}$ & 1.89 & 0.001 & Sugar & $\begin{array}{l}-0.488^{* * *} \\
(0.064)\end{array}$ & 1.52 & 0.017 \\
\hline Coffee & $\begin{array}{l}-0.301 \\
(0.224)\end{array}$ & 0.46 & 0.999 & Canned Peas & $\begin{array}{l}-0.939 \\
(0.424)\end{array}$ & 1.33 & 0.102 \\
\hline Corn Flakes & $\begin{array}{l}-0.457 \\
(0.151)\end{array}$ & 0.96 & 0.544 & Tennis Balls & $\begin{array}{l}-1.107^{*} \\
(0.133)\end{array}$ & 1.77 & 0.002 \\
\hline Frozen Com & $\begin{array}{l}-1.684 \\
(0.264)\end{array}$ & 1.26 & 0.131 & Tissue & $\begin{array}{l}-1.030^{* *} \\
(0.127)\end{array}$ & 1.99 & 0.001 \\
\hline Game & $\begin{array}{l}-0.568 \\
(0.145)\end{array}$ & 1.03 & 0.417 & Canned Tomatoes & $\begin{array}{l}-2.047 \\
(0.370)\end{array}$ & 1.31 & 0.105 \\
\hline Jeans & $\begin{array}{l}-0.641 \\
(0.131)\end{array}$ & 1.17 & 0.215 & Toothpaste & $\begin{array}{l}-0.270 \\
(0.131)\end{array}$ & 0.93 & 0.604 \\
\hline Liquor & $\begin{array}{l}-1.577 \\
(0.470)\end{array}$ & 0.93 & 0.599 & Canned Tuna & $\begin{array}{l}-1.103^{* *} \\
(0.137)\end{array}$ & 1.65 & 0.006 \\
\hline Man's Shirt & $\begin{array}{l}-0.827 \\
(0.112)\end{array}$ & 1.19 & 0.191 & Underwear & $\begin{array}{l}-0.780 \\
(0.119)\end{array}$ & 1.72 & 0.003 \\
\hline Orange Juice & $\begin{array}{l}-1.084 \\
(0.207)\end{array}$ & 1.66 & 0.011 & Washing Powder & $\begin{array}{l}-2.907 \\
(0.490)\end{array}$ & 1.80 & 0.005 \\
\hline Canned Peaches & $\begin{array}{l}-1.024 \\
(0.183)\end{array}$ & 1.03 & 0.433 & Wine & $\begin{array}{l}-0.746 \\
(0.127)\end{array}$ & 1.56 & 0.014 \\
\hline
\end{tabular}

Notes: Standard errors are in parentheses, and '*', ‘**, ‘***', denote significant at the $1 \%, 5 \%$, and $10 \%$ levels. For each good, the regression run was:

$\Delta Q_{i j, k, t}=\beta Q_{i j, k, t-1}+\sum_{m=1}^{s(k)} \gamma_{m} \Delta Q_{i j, k s-m}+$ dummies $+\varepsilon_{i j, k, t}$, where, $Q_{i j, k, t}$, is defined as the percentage difference in price of commodity $k$ at time $t$ between cities $i$ and $j$, i.e., $Q_{i j, k, t}=\ln \left(P_{i, k, t} / P_{j, k, t}\right) . s(k)$ is chosen as the highest significant lag from a preliminary regression including 16 lags. The F-Test is a test of the joint significance of city-pair dummies. New Orleans is defined as the benchmark city. 
TABLE IV: PANEL UNIT ROOT TESTS:

with seasonal and individual specific fixed effects

\section{Panel B: Perishables and Services}

\begin{tabular}{|c|c|c|c|c|c|c|c|}
\hline \multirow{2}{*}{$\frac{\text { Good }}{\text { Perishables: }}$} & Beta & $F$-test & signif. & Good & Beta & $\gamma_{\text {-test }}$ & signif. \\
\hline & & & & & & & \\
\hline Bacon & $\begin{array}{l}-0.933 \\
(0.040)\end{array}$ & 0.79 & 0.836 & McDonalds & $\begin{array}{l}-1.184^{* *} \\
(0.148)\end{array}$ & 1.96 & 0.001 \\
\hline Bananas & $\begin{array}{l}-1.601^{* *} \\
(0.085)\end{array}$ & 1.47 & 0.028 & Pizza & $\begin{array}{l}-0.569 \\
(0.097)\end{array}$ & 1.22 & 0.159 \\
\hline Bread & $\begin{array}{l}-0.594^{* *} \\
(0.027)\end{array}$ & 1.58 & 0.009 & Services: & & & \\
\hline Cheese & $\begin{array}{l}-0.608 \\
(0.039)\end{array}$ & 1.46 & 0.029 & Appliance repair & $\begin{array}{l}-0.237^{* *} \\
(0.029)\end{array}$ & 2.08 & 0.001 \\
\hline Eggs & $\begin{array}{l}-0.546 \\
(0.047)\end{array}$ & 1.23 & 0.153 & Auto Maintenance & $\begin{array}{l}-0.491 \\
(0.118)\end{array}$ & 1.45 & 0.033 \\
\hline Ground Beef & $\begin{array}{l}-1.508^{*} \\
(0.054)\end{array}$ & 2.39 & 0.001 & Beauty Salon & $\begin{array}{l}-0.235 \\
(0.057)\end{array}$ & 1.03 & 0.420 \\
\hline Lettuce & $\begin{array}{l}-1.799 * \\
(0.076)\end{array}$ & 1.71 & 0.004 & Bowling & $\begin{array}{l}-0.418 \\
(0.072)\end{array}$ & 2.72 & 0.001 \\
\hline Margarine & $\begin{array}{l}-1.173 \\
(0.045)\end{array}$ & 2.06 & 0.001 & Dentist & $\begin{array}{l}-0.360 \\
(0.060)\end{array}$ & 1.13 & 0.266 \\
\hline Milk & $\begin{array}{l}-0.360^{*} \\
(0.023)\end{array}$ & 1.27 & 0.116 & Doctor & $\begin{array}{l}-0.535 \\
(0.087)\end{array}$ & 2.08 & 0.001 \\
\hline Potatoes & $\begin{array}{l}-1.569 * * * \\
(0.061)\end{array}$ & 2.68 & 0.001 & Dry Cleaning & $\begin{array}{l}-0.403 \\
(0.073)\end{array}$ & 2.06 & 0.001 \\
\hline Steak & $\begin{array}{l}-0.740^{* *} \\
(0.041)\end{array}$ & 0.19 & 1.000 & Hospital Room & $\begin{array}{l}-0.060 \\
(0.053)\end{array}$ & 1.69 & 0.004 \\
\hline Whole Chicken & $\begin{array}{l}-0.705 \\
(0.022)\end{array}$ & 7.87 & 0.001 & Man's Haircut & $\begin{array}{l}-0.449 \\
(0.065)\end{array}$ & 1.84 & 0.001 \\
\hline Fried Chicken & $\begin{array}{l}-1.677^{* *} \\
(0.047)\end{array}$ & 1.36 & 0.067 & Movie & $\begin{array}{l}-0.466 \\
(0.160)\end{array}$ & 0.84 & 0.750 \\
\hline
\end{tabular}

Notes: Standard errors are in parentheses, and (*), (**), ' $* * *$ ', denote significant at the $1 \%, 5 \%$, and $10 \%$ levels. For each good, the regression run was:

$\Delta Q_{i j, k, t}=\beta Q_{i j, k, t-1}+\sum_{m=1}^{s(k)} \gamma_{m} \Delta Q_{i j, k, t-m}+$ dummies $+\varepsilon_{i j, k, t}$, where, $Q_{i j, k, t}$, is defined as the percentage difference in price of commodity $k$ at time $t$ between cities $i$ and $j$, i.e., $Q_{i j, k, t}=\ln \left(P_{i, k, t} / P_{j, k, t}\right) . s(k)$ is chosen as the highest significant lag from a preliminary regression including 16 lags. The F-Test is a test of the joint significance of city-pair dummies. New Orleans is defined as the benchmark city. 


\section{Panel A: Non-Perishables}

\begin{tabular}{|c|c|c|c|c|c|c|c|}
\hline Good & Beta & \# lags & $\# \boldsymbol{o b s}$ & Good & Beta & \# lags & \#obs \\
\hline Asprin & $\begin{array}{l}-0.250^{*} \\
(0.054)\end{array}$ & 15 & 503 & Shampoo & $\begin{array}{l}-0.347^{*} \\
(0.080)\end{array}$ & 16 & 465 \\
\hline Baby food & $\begin{array}{l}-0.064^{* * *} \\
(0.039)\end{array}$ & 16 & 474 & Shortening & $\begin{array}{l}-0.111^{*} \\
(0.045)\end{array}$ & 16 & 474 \\
\hline Beer & $\begin{array}{l}-0.085^{*} \\
(0.029)\end{array}$ & 13 & 585 & Soft Drink & $\begin{array}{l}-0.111^{*} \\
(0.039)\end{array}$ & 12 & 639 \\
\hline Cigarettes & $\begin{array}{l}-0.044^{* *} \\
(0.025)\end{array}$ & 16 & 474 & Sugar & $\begin{array}{l}-0.145^{*} \\
(0.037)\end{array}$ & 13 & 583 \\
\hline Coffee & $\begin{array}{l}-0.043 \\
(0.080)\end{array}$ & 14 & 258 & Canned Peas & $\begin{array}{l}-0.181^{* * *} \\
(0.123)\end{array}$ & 15 & 206 \\
\hline Com Flakes & $\begin{array}{l}-0.081 \\
(0.064)\end{array}$ & 16 & 463 & Tennis Balls & $\begin{array}{l}-0.222^{*} \\
(0.071)\end{array}$ & 16 & 465 \\
\hline Frozen Com & $\begin{array}{l}-0.475^{*} \\
(0.095)\end{array}$ & 16 & 321 & Tissue & $\begin{array}{l}-0.043 \\
(0.043)\end{array}$ & 16 & 474 \\
\hline Game & $\begin{array}{l}-0.071^{* *} \\
(0.039)\end{array}$ & 15 & 503 & Canned Tomatoes & $\begin{array}{l}-0.157^{* *} \\
(0.082)\end{array}$ & 13 & 242 \\
\hline Jeans & $\begin{array}{l}-0.147^{*} \\
(0.059)\end{array}$ & 13 & 585 & Toothpaste & $\begin{array}{l}-0.092 \\
(0.071)\end{array}$ & 15 & 503 \\
\hline Liquor & $\begin{array}{l}-0.027 \\
(0.031)\end{array}$ & 16 & 163 & Canned Tuna & $\begin{array}{l}-0.210^{*} \\
(0.054)\end{array}$ & 15 & 502 \\
\hline Man's Shirt & $\begin{array}{l}-0.193^{*} \\
(0.051)\end{array}$ & 15 & 503 & Underwear & $\begin{array}{l}-0.068^{* * *} \\
(0.043)\end{array}$ & 16 & 465 \\
\hline Orange Juice & $\begin{array}{l}-0.290^{*} \\
(0.055)\end{array}$ & 14 & 212 & Washing Powder & $\begin{array}{l}-0.129^{* *} \\
(0.064)\end{array}$ & 16 & 182 \\
\hline Canned Peaches & $\begin{array}{l}-0.138^{*} \\
(0.033)\end{array}$ & 14 & 233 & Wine & $\begin{array}{l}-0.105^{*} \\
(0.027)\end{array}$ & 16 & 465 \\
\hline
\end{tabular}

Notes: Standard errors are in parentheses, and '*', '**', '***), denote significant at the $1 \%, 5 \%$, and $10 \%$ levels. For each good, the regression run was:

$\Delta Z_{i j, k, t}=\beta Z_{i j, k, t-1}+\sum_{m=1}^{s(k)} \gamma_{m} \Delta Z_{i j, k, t-m}+\varepsilon_{i j, k, t}$, where, $Z_{i j, k, t}$, is defined as the 'tax-adjusted' percentage difference in price of commodity $k$ at time $t$ between cities $i$ and $j$. See text for details. $s(k)$ is chosen as the highest significant lag from a preliminary regression including 16 lags. The F-Test is a test of the joint significance of city-pair dummies. New Orleans is defined as the benchmark city. 
TABLE V: PANEL UNIT ROOT TESTS INCORPORATING TAXES

Panel B: Perishables

\begin{tabular}{|c|c|c|c|c|c|c|c|}
\hline \multirow{2}{*}{$\begin{array}{l}\text { Good } \\
\text { Perishables: }\end{array}$} & Beta & \# lags & \multirow{2}{*}{ \#obs } & \multirow[t]{2}{*}{ Good } & \multirow[t]{2}{*}{ Beta } & \# lags & \multirow[t]{2}{*}{$\#$ \#bs } \\
\hline & & & & & & & \\
\hline Bacon & $\begin{array}{l}-0.502 * \\
(0.072)\end{array}$ & 16 & 511 & McDonalds & $\begin{array}{l}-0.122^{* *} \\
(0.052)\end{array}$ & * 16 & 465 \\
\hline Bananas & $\begin{array}{l}-0.408^{*} \\
(0.082)\end{array}$ & 16 & 510 & Pizza & $\begin{array}{l}-0.157^{*} \\
(0.029)\end{array}$ & 15 & 503 \\
\hline Bread & $\begin{array}{l}-0.203 * \\
(0.030)\end{array}$ & 10 & 1358 & & & & \\
\hline Cheese & $\begin{array}{l}-0.060^{* * *} \\
(0.036)\end{array}$ & 14 & 541 & & & & \\
\hline Eggs & $\begin{array}{l}0.137 * \\
(0.049)\end{array}$ & 16 & 474 & & & & \\
\hline Ground Beef & $\begin{array}{l}-0.270^{*} \\
(0.055)\end{array}$ & 12 & 688 & & & & \\
\hline Lettuce & $\begin{array}{l}-0.210^{*} \\
(0.071)\end{array}$ & 15 & 512 & & & & \\
\hline Margarine & $\begin{array}{l}-0.000 \\
(0.050)\end{array}$ & 16 & 467 & & & & \\
\hline Milk & $\begin{array}{l}-0.135^{*} \\
(0.025)\end{array}$ & 13 & 594 & & & & \\
\hline Potatoes & $\begin{array}{l}-0.036^{*} \\
(0.056)\end{array}$ & 15 & 579 & & & & \\
\hline Steak & $\begin{array}{l}-0.004^{*} \\
(0.041)\end{array}$ & 16 & 474 & & & & \\
\hline Whole Chicken & $\begin{array}{l}-0.220^{*} \\
(0.024)\end{array}$ & 10 & 1732 & & & & \\
\hline Fried Chicken & $\begin{array}{l}-0.170^{*} \\
(0.047)\end{array}$ & 16 & 465 & & & & \\
\hline
\end{tabular}

Notes: Standard errors are in parentheses, and '*', '**', '***', denote significant at the $1 \%, 5 \%$, and $10 \%$ levels. For each good, the regression run was:

$\Delta Z_{i j, k, t}=\beta Z_{i j, k, t-1}+\sum_{m=1}^{s(k)} \gamma_{m} \Delta Z_{i j, k, t-m}+\varepsilon_{i j, k, t}$, where, $Z_{i j, k, t}$, is defined as the 'tax-adjusted' percentage difference in price of commodity $k$ at time $t$ between cities $i$ and $j$. See text for details. $s(k)$ is chosen as the highest significant lag from a preliminary regression including 16 lags. New Orleans is defined as the benchmark city. 
TABLE VI: PANEL UNIT ROOT TESTS INCORPORATING TAXES:

with seasonal and individual specific fixed effects

\begin{tabular}{|c|c|c|c|c|c|c|c|}
\hline \multicolumn{8}{|c|}{ Panel A: Non-Perishables } \\
\hline Good & Beta & F-test & signif. & Good & Beta & F-test & signif. \\
\hline Asprin & $\begin{array}{l}-0.656 \\
(0.101)\end{array}$ & 0.95 & 0.577 & Shampoo & $\begin{array}{l}-1.601 \\
(0.218)\end{array}$ & 1.30 & 0.101 \\
\hline Baby food & $\begin{array}{l}-1.100 * \\
(0.124)\end{array}$ & 2.63 & 0.001 & Shortening & $\begin{array}{l}-0.633 \\
(0.119)\end{array}$ & 1.48 & 0.026 \\
\hline Beer & $\begin{array}{l}-0.685^{* * *} \\
(0.095)\end{array}$ & 1.51 & 0.019 & Soft Drink & $\begin{array}{l}-0.450 \\
(0.099)\end{array}$ & 1.49 & 0.023 \\
\hline Cigarettes & $\begin{array}{l}-0.828^{* *} \\
(0.106)\end{array}$ & 1.86 & 0.001 & Sugar & $\begin{array}{l}-0.490^{* *} \\
(0.062)\end{array}$ & 1.48 & 0.025 \\
\hline Coffee & $\begin{array}{l}-0.349 \\
(0.242)\end{array}$ & 0.47 & 0.998 & Canned Peas & $\begin{array}{l}-0.916 \\
(0.418)\end{array}$ & 1.39 & 0.071 \\
\hline Corn Flakes & $\begin{array}{l}-0.372 \\
(0.153)\end{array}$ & 0.85 & 0.751 & Tennis Balls & $\begin{array}{l}-1.088^{* *} \\
(0.133)\end{array}$ & 1.74 & 0.003 \\
\hline Frozen Com & $\begin{array}{l}-1.855 \\
(0.286)\end{array}$ & 1.31 & 0.101 & Tissue & $\begin{array}{l}-1.030^{* *} \\
(0.127)\end{array}$ & 1.89 & 0.001 \\
\hline Game & $\begin{array}{l}-0.591 \\
(0.152)\end{array}$ & 1.06 & 0.367 & Canned Tomatoes & $\begin{array}{l}-2.020 \\
(0.358)\end{array}$ & 1.40 & 0.061 \\
\hline Jeans & $\begin{array}{l}-0.634 \\
(0.133)\end{array}$ & 1.13 & 0.260 & Toothpaste & $\begin{array}{l}-0.341 \\
(0.137)\end{array}$ & 0.86 & 0.734 \\
\hline Liquor & $\begin{array}{l}-1.654 \\
(0.462)\end{array}$ & 1.10 & 0.332 & Canned Tuna & $\begin{array}{l}-1.095^{* *} \\
(0.134)\end{array}$ & 1.68 & 0.005 \\
\hline Man's Shirt & $\begin{array}{l}-0.816 \\
(0.111)\end{array}$ & 1.21 & 0.176 & Underwear & $\begin{array}{l}-0.773 \\
(0.118)\end{array}$ & 1.73 & 0.003 \\
\hline Orange Juice & $\begin{array}{l}-1.083 \\
(0.207)\end{array}$ & 1.71 & 0.008 & Washing Powder & $\begin{array}{l}-2.872 \\
(0.491)\end{array}$ & 1.73 & 0.008 \\
\hline Canned Peaches & $\begin{array}{l}-1.040 \\
(0.174)\end{array}$ & 1.09 & 0.342 & Wine & $\begin{array}{l}-0.758 \\
(0.124)\end{array}$ & 1.61 & 0.009 \\
\hline
\end{tabular}

Notes: Standard errors are in parentheses, and ' $*$ ', '**', '***), denote significant at the $1 \%, 5 \%$, and $10 \%$ levels. For each good, the regression run was:

$\Delta Z_{i j, k, t}=\beta Z_{i j, k, t-1}+\sum_{m=1}^{s(k)} \gamma_{m} \Delta Z_{i j, k, t-m}+$ dummies $+\varepsilon_{i j, k, t}$, where, $Z_{i j, k, t}$, is defined as the 'taxadjusted' percentage difference in price of commodity $k$ at time $t$ between cities $i$ and $j$. See text for details. $s(k)$ is chosen as the highest significant lag from a preliminary regression including 16 lags. The F-Test is a test of the joint significance of city-pair dummies. New Orleans is defined as the benchmark city. 
TABLE VI: PANEL UNIT ROOT TESTS INCORPORATING TAXES:

with seasonal and individual specific fixed effects

Panel B: Perishables

\begin{tabular}{|c|c|c|c|c|c|c|c|}
\hline Good & Beta & F-test & signif. & Good & Beta & F-iest & signif. \\
\hline \multicolumn{8}{|l|}{ Perishables: } \\
\hline Bacon & $\begin{array}{l}-0.911 \\
(0.040)\end{array}$ & 0.71 & 0.925 & McDonalds & $\begin{array}{l}-1.197 \\
(0.148)\end{array}$ & 1.71 & 0.004 \\
\hline Bananas & $\begin{array}{l}-1.545 * * \\
(0.085)\end{array}$ & 1.47 & 0.029 & Pizza & $\begin{array}{l}-0.622 \\
(0.097)\end{array}$ & 1.29 & 0.107 \\
\hline Bread & $\begin{array}{l}-0.588 * * \\
(0.027)\end{array}$ & 1.58 & 0.009 & & & & \\
\hline Cheese & $\begin{array}{l}-0.638 \\
(0.039)\end{array}$ & 1.41 & 0.045 & & & & \\
\hline Eggs & $\begin{array}{l}-0.474 \\
(0.047)\end{array}$ & 1.20 & 0.177 & & & & \\
\hline Ground Beef & $\begin{array}{l}-1.133^{*} \\
(0.054)\end{array}$ & 2.41 & 0.001 & & & & \\
\hline Lettuce & $\begin{array}{l}-1.806^{*} \\
(0.076)\end{array}$ & 1.84 & 0.001 & & & & \\
\hline Margarine & $\begin{array}{l}-1.209 \\
(0.045)\end{array}$ & 2.13 & 0.001 & & & & \\
\hline Milk & $\begin{array}{l}-0.322 \\
(0.023)\end{array}$ & 1.08 & 0.337 & & & & \\
\hline Potatoes & $\begin{array}{l}-1.460 \\
(0.061)\end{array}$ & 2.68 & 0.001 & & & & \\
\hline Steak & $\begin{array}{l}-0.736^{*} \\
(0.041)\end{array}$ & 0.39 & 1.000 & & & & \\
\hline Whole Chicken & $\begin{array}{l}-0.726 \\
(0.022)\end{array}$ & 8.09 & 0.001 & & & & \\
\hline Fried Chicken & $\begin{array}{l}-1.593 * * * \\
(0.047)\end{array}$ & * 1.25 & 0.134 & & & & \\
\hline
\end{tabular}

Notes: Standard errors are in parentheses, and '*', ‘**', '***', denote significant at the $1 \%, 5 \%$, and $10 \%$ levels. For each good, the regression run was:

$\Delta Z_{i j, k, t}=\beta Z_{i j, k, t-1}+\sum_{m=1}^{s(k)} \beta_{m} \Delta Z_{i j, k, t-m}+$ dummies $+\varepsilon_{i j, k, t}$, where, $Z_{i j, k, t}$, is defined as the 'taxadjusted' percentage difference in price of commodity $k$ at time $t$ between cities $i$ and $j$. See text for details. $s(k)$ is chosen as the highest significant lag from a preliminary regression including 16 lags. The F-Test is a test of the joint significance of city-pair dummies. New Orleans is defined as the benchmark city. 
TABLE VII: THE IMPACT OF MEASUREMENT ERRORS

ON ESTIMATED RATES OF CONVERGENCE

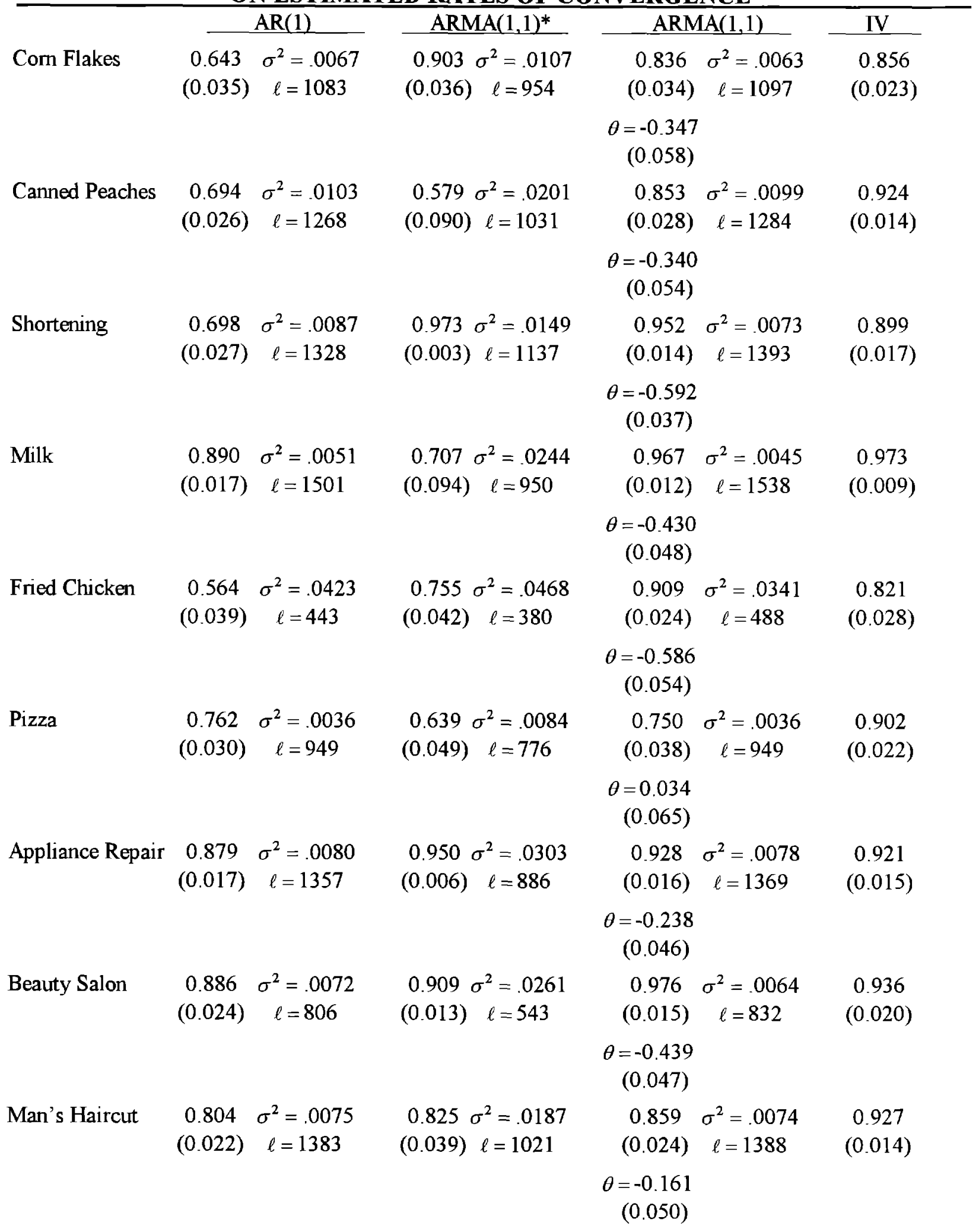

Notes: Standard errors in parentheses, $\ell=$ the value of the $\log$ likelihood function, and $\sigma^{2}=$ the estimate of the sample variance. Columns 1 - 3 report maximum likelihood estimates pooling data from 10 cities. ${ }^{*}$ Column 2 imposes the restriction that the MA(1) coefficient $(\theta)=-1 *$ the $\operatorname{AR}(1)$ coefficient. The estimates in Column 4 were obtained instrumenting $Q_{i j, k, t-1}$ with $Q_{i j, k, t-3}$. The 10 cities used are: Mobile, Al; Blythe, Ca; Denver, Co; Indianapolis, In; Lexington, Ky; Louisville, Ky; St. Louis, Mo; Hastings, Ne; Rapid City, SD; and Houston, Tx. 
Perishables

$\underline{\text { Regression } 1} \underline{\text { Regression } 2}$ Regression $3 \quad$ Regression 4

$\begin{array}{lrrrr}Q_{i j, k, t-1} & -0.474 & -0.551 & -0.195 & -0.260 \\ Q^{2} i j, k, t-1 & (0.004) & (0.004) & (0.008) & (0.009) \\ & -0.097 & -0.125 & 0.021 & -0.071 \\ & (0.009) & (0.011) & (0.017) & (0.019)\end{array}$

Non-Perishables

$\begin{array}{lrrrr}Q_{i j, k,-1} & -0.376 & -0.412 & -0.105 & -0.125 \\ Q^{2}{ }_{i j, k, t-1} & (0.004) & (0.004) & (0.009) & (0.010) \\ & -0.243 & -0.167 & -0.087 & -0.073 \\ & (0.012) & (0.013) & (0.026) & (0.029)\end{array}$

Services

$\begin{array}{lrrrr}Q_{i j, k, t-1} & -0.134 & -0.141 & -0.029 & -0.053 \\ Q^{2}{ }_{j j, k, t-1} & (0.004) & (0.004) & (0.009) & (0.009) \\ & -0.083 & -0.063 & -0.076 & -0.037 \\ & (0.011) & (0.012) & (0.024) & (0.027)\end{array}$

Std. error of Regression

.1343

106910

Number of Observations

Product dummies

City dummies

no

no

lagged dependent variable

no

1321
106910
yes
no
no

$\begin{array}{cc}1224 & 1212 \\ 26989 & 26989 \\ \text { no } & \text { yes } \\ \text { no } & \text { yes } \\ \text { yes } & \text { yes }\end{array}$

Notes: Standard errors in parentheses. For columns 1 and 2, the regression run was:

$$
\Delta Q_{i j, k, t}=\sum_{n=1}^{3} \beta_{n} Q_{i j, k, t-1}+\sum_{n=1}^{3} \gamma_{n} Q_{i j, k, t-1}^{2}+\operatorname{dummies}+\varepsilon_{i j, k, t}
$$

For columns 3 and 4, the regression run was:

$$
\Delta Q_{i j, k, t}=\sum_{n=1}^{3} \beta_{n} Q_{i j, k, t-1}+\sum_{n=1}^{3} \gamma_{n} Q_{i j, k, t-1}^{2}+\sum_{m=1}^{16} \delta_{m} \Delta Q_{i j, k, t-m}+\mathrm{dummies}+\varepsilon_{i j, k, t}, \text { where } \mathbf{n}=1 \text { if } \mathbf{k}
$$

is perishable, $\mathbf{n}=2$ if $\mathbf{k}$ is non-perishable, and $\mathbf{n}=3$ if $\mathbf{k}$ is a service, and, $Q_{i j, k, t}$, is defined as the percentage difference in price of commodity $k$ at time $t$ between cities $\mathrm{i}$ and $\mathrm{j}$, $\mathrm{i}$.e., $Q_{i j, k, t}=\ln \left(P_{i, k, t} / P_{j, k, t}\right)$. New Orleans is defined as the benchmark city. 


\section{Perishables}

$\begin{array}{lrrrr}Q_{i j, k, t-1} & -1.174 & -1.150 & -0.691 & -0.622 \\ & (0.042) & (0.042) & (0.074) & (0.075) \\ Q_{i j, k,-1} * \text { ldist } & 0.104 & 0.090 & 0.073 & 0.054 \\ & (0.006) & (0.006) & (0.011) & (0.011)\end{array}$

Non-Perishables

$\begin{array}{lrrrr}Q_{i j, k, t-1} & -0.570 & -0.609 & -0.265 & -0.283 \\ Q_{i j, k, t-1}^{*}{ }^{*} \text { ldist } & (0.040) & (0.039) & (0.075) & (0.076) \\ & 0.031 & 0.031 & 0.025 & 0.024 \\ & (0.006) & (0.006) & (0.011) & (0.011)\end{array}$

\section{Services}

$\begin{array}{lrrrr}Q_{i j, k s-1} & -0.274 & -0.303 & -0.070 & -0.103 \\ Q_{i j, k, t-1} * \text { ldist } & (0.045) & (0.046) & (0.078) & (0.080) \\ & 0.021 & 0.025 & 0.007 & 0.008 \\ & (0.007) & (0.007) & (0.012) & (0.012)\end{array}$

Ln distance

-.0012
$(.0001)$

$-.0004$

$-.0005$

.0004

(.0003)

(.0001)

(.0007)

Std. error of Regression

Number of Observations

no

yes

yes

yes

Notes: "Ln" refers to the natural log, standard errors in parentheses. For columns 1 and 2 , the regression run was:

$$
\Delta Q_{i j, k, t}=\theta \ln \text { distance }+\sum_{n=1}^{3} \beta_{n} Q_{i j, k, t-1}+\sum_{n=1}^{3} \gamma_{n} Q_{i j, k, t-1} \ln \text { distance }+\operatorname{dummies}+\varepsilon_{i j, k, r} .
$$

For columns 3 and 4 , the regression run was:

$\Delta Q_{i j, k, t}=\theta \ln$ distance $+\sum_{n=1}^{3} \beta_{n} Q_{i j, k, t-1}+\sum_{n=1}^{3} \gamma_{n} Q_{i j, k, t-1} \operatorname{lndistance}+\sum_{m=1}^{16} \delta_{m} \Delta Q_{i j, k, t-m}+$ dummies $+\varepsilon_{i j, k, t}$, where $\mathrm{n}=1$ if $\mathrm{k}$ is perishable, $\mathrm{n}=2$ if $\mathrm{k}$ is non-perishable, and $\mathrm{n}=3$ if $\mathrm{k}$ is a service, and, $Q_{i j, k, t}$, is defined as the percentage difference in price of commodity $\mathrm{k}$ at time $\mathrm{t}$ between cities $\mathrm{i}$ and $\mathrm{j}$, i.e., $Q_{i j, k, t}=\ln \left(P_{i, k, t} / P_{j, k, t}\right)$. New Orleans is defined as the benchmark city. 
TABLE A1: CITIES AND COMMODITIES INCLUDED

\begin{tabular}{|c|c|c|c|}
\hline & Cities & & Goods \\
\hline$\overline{\mathrm{Cl}}$ & Birmingham AL & $\mathrm{G} 1$ & Appliance Repair \\
\hline $\mathrm{C} 2$ & Mobile AL & $\mathrm{G} 2$ & Aspirin \\
\hline C3 & Blythe CA & G3 & Auto Maintenance \\
\hline $\mathrm{C} 4$ & Indio CA & G4 & Baby food \\
\hline C5 & Palm Springs CA & G5 & Bacon \\
\hline C6 & Denver CO & G6 & Bananas \\
\hline $\mathrm{C} 7$ & Lakeland FL & G7 & Beauty Salon \\
\hline $\mathrm{C} 8$ & Boise ID & G8 & Beer \\
\hline C9 & Champaign,Urbana IL & G9 & Bowling \\
\hline $\mathrm{C} 10$ & Peoria IL & G10 & Bread \\
\hline $\mathrm{C} 11$ & Ft. Wayne IN & G11 & Cheese \\
\hline $\mathrm{CI} 2$ & Indianapolis IN & G12 & Cigarettes \\
\hline $\mathrm{C} 13$ & Cedar Rapids IA & G13 & Coffee \\
\hline $\mathrm{C} 14$ & Lexington $\mathrm{KY}$ & G14 & Corn Flakes \\
\hline $\mathrm{C} 15$ & Louisville KY & G15 & Dentist \\
\hline $\mathrm{C} 16$ & Baton Rouge LA & G16 & Doctor \\
\hline $\mathrm{C} 17$ & Lafayette LA & G17 & Dry Cleaning \\
\hline $\mathrm{C} 18$ & New Orleans LA & G18 & Eggs \\
\hline $\mathrm{C} 19$ & Benton Harbor MI & G19 & Fried Chicken \\
\hline $\mathrm{C} 20$ & Traverse City MI & G20 & Frozen Corn \\
\hline $\mathrm{C} 21$ & Columbus MS & G21 & Game \\
\hline $\mathrm{C} 22$ & St. Joseph MO & G22 & Ground Beef \\
\hline $\mathrm{C} 23$ & St. Louis MO & G23 & Hospital Room \\
\hline $\mathrm{C} 24$ & Falls City NE & G24 & Jeans \\
\hline $\mathrm{C} 25$ & Hastings NE & G25 & Lettuce \\
\hline $\mathrm{C} 26$ & Omaha NE & G26 & Liquor \\
\hline $\mathrm{C} 27$ & Reno,Sparks NV & G27 & Man's Haircut \\
\hline $\mathrm{C} 28$ & Newark NJ & G28 & Man's Shirt \\
\hline $\mathrm{C} 29$ & New York NY & G29 & Margarine \\
\hline $\mathrm{C} 30$ & Hickory NC & G30 & McDonalds \\
\hline $\mathrm{C} 31$ & Columbus $\mathrm{OH}$ & G31 & Milk \\
\hline $\mathrm{C} 32$ & Altoona PA & G32 & Movie \\
\hline C33 & Rapid City SD & G33 & Canned Orange juice \\
\hline $\mathrm{C} 34$ & Vermillion SD & G34 & Canned Peaches \\
\hline $\mathrm{C} 35$ & Chattanooga TN & G35 & Pizza \\
\hline $\mathrm{C} 36$ & Knoxville TN & G36 & Potatoes \\
\hline $\mathrm{C} 37$ & Abilene TX & G37 & Shampoo \\
\hline C38 & El Paso TX & G38 & Shortening \\
\hline C39 & Ft. Worth TX & G39 & Soft Drink \\
\hline $\mathrm{C} 40$ & Houston TX & G40 & Steak \\
\hline $\mathrm{C} 41$ & Lubbock TX & G41 & Sugar \\
\hline $\mathrm{C} 42$ & Salt Lake City UT & G42 & Canned Peas \\
\hline $\mathrm{C} 43$ & Charleston WV & G43 & Tennis balls \\
\hline $\mathrm{C} 44$ & Appleton WI & G44 & Tissue \\
\hline $\mathrm{C} 45$ & Eau Claire WI & G45 & Canned Tomatoes \\
\hline $\mathrm{C} 46$ & Madison WI & G46 & Toothpaste \\
\hline $\mathrm{C} 47$ & Oshkosh WI & G47 & Tuna \\
\hline \multirow[t]{4}{*}{$\mathrm{C} 48$} & Casper WY & G48 & Underwear \\
\hline & & G49 & Washing Powder \\
\hline & & G50 & Whole Chicken \\
\hline & & G51 & Wine \\
\hline
\end{tabular}




\begin{tabular}{|c|c|c|}
\hline Item & Date added & Description \\
\hline Appliance Repair & 75.1 & $\begin{array}{l}\text { Service call excluding parts color TV (75.1-79.1); Washing } \\
\text { Machine (79.2-92.4). }\end{array}$ \\
\hline Aspirin & 82.2 & Bayer brand, 100-tablets, bottle $325 \mathrm{mg}$ tablets (82.2-92.4). \\
\hline Auto Maintenance & 79.2 & $\begin{array}{l}\text { Average price to balance two front wheels }(79.2-84.1) \text {; average } \\
\text { price to balance one front wheel }(84.2-88.3) \text {; average price to } \\
\text { computer or spin balance one front wheel }(88.4-92.4) \text {. }\end{array}$ \\
\hline Baby food & 75.1 & Jar $41 / 2$ oz strained vegetables. \\
\hline Bacon & 75.1 & $\mathrm{lb}$, or national brands. \\
\hline Bananas & 75.1 & lb. \\
\hline Beauty Salon & 82.2 & Woman's visit, shampoo, trim and blow-dry. \\
\hline Beer & 82.2 & $\begin{array}{l}6 \text { pack, } 12 \text { oz. containers, excluding deposit, Miller Lite or } \\
\text { Budweiser. }\end{array}$ \\
\hline Bowling & 75.1 & Price per line evening price. \\
\hline Bread & 75.1 & $24 \mathrm{oz}(75.1-80.2) ; 20 \mathrm{oz}(80.3-92.4)$ \\
\hline Cheese & 82.2 & Parmesan, grated 8 oz. canister, Kraft. \\
\hline Cigarettes & 75.1 & Carton Winston king-size. \\
\hline Coffee & 75.1 & $\begin{array}{l}2 \mathrm{lbs}(75.1-80.2) ; 1 \mathrm{lb}(80.3-88.3) ; 13 \mathrm{oz}(88.4-92.4) \text {; Maxwell } \\
\text { House Hills Brothers Folgers. }\end{array}$ \\
\hline Com Flakes & 79.2 & 12 oz. Kellogg's or Post Toasties (79.2-80.3); $18 \mathrm{oz} .(80.4-92.4)$. \\
\hline Dentist & 75.1 & $\begin{array}{l}\text { Office Visit, teeth cleaning and inspection, no x-ray or fluoride } \\
\text { treatment. }\end{array}$ \\
\hline Doctor & 75.1 & Office Visit, general practitioner routine exam of existing patient. \\
\hline Dry Cleaning & 75.1 & Man's two piece suit. \\
\hline Eggs & 75.1 & Doz. large Grade A. \\
\hline
\end{tabular}


Fried Chicken

82.2

Frozen Com

84.1

Game

Ground Beef

Hospital Room

Jeans

Lettuce

75.1

75.1

Liquor

Man's Haircut

Man's Shirt

Margarine

McDonalds

Milk

Movie

Canned Orange juice

Canned Peaches

Pizza

Potatoes

Shampoo

Shortening
75.1

82.2

75.1

82.2

75.1

82.2

75.1

75.1

75.1

75.1

8.2

75.1
Breast and drumstick (82.2-83.4), thigh and drumstick (84.192.4), Church's, or Kentucky Fried Chicken if available.

Frozen, whole kemel, $10 \mathrm{oz}$. package.

Monopoly, standard (No. 9) edition.

$\mathrm{lb}$, or Hamburger.

Semi-private cost per day

Levi's straight leg, sizes $28 / 30$ to $34 / 36$ (82.2-87.4), Levi's 501 (88.1-91.3); Levi's 505s or 501s (91.4-92.4).

Each.

$750 \mathrm{ml}$ bottle Seagram's 7 Crown (75.1-88.3); J\&B Scotch (88.492.4).

No styling.

Arrow or Van Heusen, white, long sleeve, cotton/polyester blend (82.2-83.4); sizes 15/32 to 16/34 (89.1-89.3); Arrow, Enro, Van Heusen, J.C. Penny, cotton/polyester (at least 55\% cotton) long sleeves (89.4-92.4).

lb.

$1 / 2 \mathrm{lb}$ patty (82.2-83.2); $1 / 4 \mathrm{lb}$. patty with cheese, pickle, onion, mustard, catsup (83.3-92.4).

$1 / 2$ gal . carton

First run indoor evening price.

6 oz can (75.1-85.4); 12 oz can (86.1-92.4)

\#2 1/2 can approx 29 oz (75.1-85.4); 29 oz (86.1-92.4); Del Monte or Libby's halves or slices.

12" - 13" thin crust, regular cheese, Pizza Hut or Pizza Inn, where available.

$10 \mathrm{lbs}$ white or red.

11 oz. container Johnson's (82.2-88.3); 15 oz. bottle (88.4-89.3); 11 oz. (89.4-90.4); 15 oz bottle (91.1); 11 oz. bottle (91.2); 15 oz. bottle Alberto VO-5 (91.3-92.4).

$3 \mathrm{lb}$ can all vegetable, Crisco brand. 


\begin{tabular}{|c|c|c|}
\hline Soft Drink & 75.1 & 1 qt Coca-Cola (75.1-79.2); 2 liter (79.3-92.4). \\
\hline Steak & 75.1 & $\begin{array}{l}\text { lb, round steak (75.1-80.3); T-bone steak (80.4-92.4) USDA } \\
\text { Choice. }\end{array}$ \\
\hline Sugar & 79.2 & 5 lbs. cane or beet $(79.2-92.3) ; 4$ lbs cane or beet. 92.4 . \\
\hline Canned Peas & 75.1 & $\begin{array}{l}\text { \#303 can } 15-17 \text { oz }(75.1-85.4) ; 17 \text { oz (86.1-92.4); Del Monte or } \\
\text { Green Giant }\end{array}$ \\
\hline Tennis balls & 82.2 & Wilson or Penn brands, yellow, can of 3 heavy duty. \\
\hline Tissue & 75.1 & $\begin{array}{l}1 \text { roll }(75.1-79.1) ; 4 \text { rolls }(79.2-80.2) \text {; Kleenex brand } 175 \text { count } \\
\text { box }(80.3-92.4) \text {. }\end{array}$ \\
\hline Canned Tomatoes & 75.1 & $\begin{array}{l}\text { \#303 can } 15-17 \text { oz (75.1-85.4); } 14.5 \text { oz (86.1-92.4); Del Monte } \\
\text { or Green Giant. }\end{array}$ \\
\hline Toothpaste & 82.2 & 6 to $7 \mathrm{oz}$. tube Crest, or Colgate. \\
\hline Tuna & 82.2 & $\begin{array}{l}6.5 \mathrm{oz} . \text {, Starkist or Chicken of the Sea, packed in oil (82:2-91.3); } \\
6.125-6.5 \mathrm{oz}(92.4) \text {. }\end{array}$ \\
\hline Underwear & 82.2 & $\begin{array}{l}\text { Package of } 3 \text { briefs, sizes } 28 / 30-34 / 36(82.2-90.3) \text {; sizes } 10-14 \\
(90.4-92.4) \text {. }\end{array}$ \\
\hline Washing Powder & 75.1 & $49 \mathrm{oz}$ (75.1-88.4); 42 oz (89.1-92.4); Giant Tide, Bold, or Cheer. \\
\hline Whole Chicken & 75.1 & lb, Grade A Frying. \\
\hline Wine & 82.2 & $\begin{array}{l}\text { Paul Masson Chablis } 750 \text { milliliter bottle }(82.2-83.4) \text {, Paul } \\
\text { Masson Chablis } 1.5 \text { liter }(84.1-90.3) \text { Gallo Sauvignon blanc } 1.5 \\
\text { liter (90.4-91.3); Gallo Chablis Blanc } 1.5 \text { liter }(91.3-92.4) \text {. }\end{array}$ \\
\hline
\end{tabular}




\begin{tabular}{|c|c|c|c|c|c|c|c|}
\hline & \multirow[t]{2}{*}{ Cities } & \multicolumn{3}{|c|}{ Grocery Items } & \multicolumn{3}{|c|}{ Non-Grocery Items } \\
\hline & & 92.4 & $75-84$ & 84-92 & 92.4 & 75-84 & 84-92 \\
\hline $\mathrm{Cl}$ & Birmingham $\mathrm{AL}$ & 8.00 & 0.00 & 3.00 & 8.00 & 0.00 & 3.00 \\
\hline $\mathrm{C} 2$ & Mobile AL & 9.00 & 1.00 & 1.00 & 9.00 & 1.00 & 1.00 \\
\hline $\mathrm{C} 3$ & Blythe CA & 7.80 & 0.00 & 7.80 & 7.80 & 0.00 & 1.80 \\
\hline $\mathrm{C} 4$ & Indio CA & 7.80 & 0.00 & 7.80 & 7.80 & 0.00 & 1.80 \\
\hline $\mathrm{C} 5$ & Palm Springs CA & 7.80 & 0.00 & 7.80 & 7.80 & 0.00 & 1.80 \\
\hline C6 & Denver CO & 6.00 & 1.00 & 0.00 & 6.00 & 1.00 & 0.00 \\
\hline $\mathrm{C} 7$ & Lakeland FL & 0.00 & 0.00 & 0.00 & 6.00 & 1.00 & 1.00 \\
\hline $\mathrm{C} 8$ & Boise ID & 5.00 & 1.50 & 0.50 & 5.00 & 1.50 & 0.50 \\
\hline $\mathrm{C9}$ & Champaign,Urbana IL & 1.00 & -4.00 & 1.00 & 7.20 & 1.00 & 2.20 \\
\hline $\mathrm{C} 10$ & Peoria IL & 7.40 & 1.00 & 2.40 & 7.20 & 1.00 & 2.20 \\
\hline $\mathrm{C} 11$ & Ft. Wayne IN & 0.00 & 0.00 & 0.00 & 5.00 & 1.00 & 0.00 \\
\hline $\mathrm{C} 12$ & Indianapolis IN & 0.00 & 0.00 & 0.00 & 5.00 & 1.00 & 0.00 \\
\hline C13 & Cedar Rapids IA & 0.00 & 0.00 & 0.00 & 5.00 & 1.00 & 1.00 \\
\hline C14 & Lexington KY & 0.00 & 0.00 & 0.00 & 6.00 & 0.00 & 1.00 \\
\hline $\mathrm{C} 15$ & Louisville KY & 0.00 & 0.00 & 0.00 & 6.00 & 0.00 & 1.00 \\
\hline $\mathrm{C} 16$ & Baton Rouge LA & 8.00 & 0.00 & 2.00 & 8.00 & 0.00 & 2.00 \\
\hline C17 & Lafayette LA & 7.50 & 0.00 & 2.50 & 7.50 & 0.00 & 2.50 \\
\hline C18 & New Orleans LA & 7.50 & 1.50 & 3.00 & 9.00 & 2.00 & 1.00 \\
\hline C19 & Benton Harbor MI & 0.00 & 0.00 & 0.00 & 4.00 & 0.00 & 0.00 \\
\hline $\mathrm{C} 20$ & Traverse City MI & 0.00 & 0.00 & 0.00 & 4.00 & 0.00 & 0.00 \\
\hline $\mathrm{C} 21$ & Columbus MS & 6.00 & 1.00 & 0.00 & 7.00 & 1.00 & 1.00 \\
\hline $\mathrm{C} 22$ & St. Joseph MO & 6.20 & 3.00 & 0.20 & 6.20 & 3.00 & 0.20 \\
\hline $\mathrm{C} 23$ & St. Louis MO & 5.70 & 2.60 & 0.10 & 5.70 & 2.60 & 0.10 \\
\hline C24 & Falls City NE & 0.00 & -2.50 & 0.00 & 5.00 & 1.50 & 1.00 \\
\hline $\mathrm{C} 25$ & Hastings NE & 0.00 & $-2,50$ & 0.00 & 6.00 & 1.50 & 2.00 \\
\hline $\mathrm{C} 26$ & Omaha NE & 0.00 & -3.50 & 0.00 & 6.50 & 2.00 & 1.00 \\
\hline $\mathrm{C} 27$ & Reno,Sparks NV & 0.00 & -3.50 & 0.00 & 7.00 & 2.50 & 1.00 \\
\hline C28 & Newark NJ & 0.00 & 0.00 & 0.00 & 7.00 & 1.00 & 1.00 \\
\hline $\mathrm{C} 29$ & New York NY & 0.00 & 0.00 & 0.00 & 8.30 & 0.30 & 0.00 \\
\hline $\mathrm{C} 30$ & Hickory NC & 6.00 & 0.50 & 1.50 & 6.00 & 0.50 & 1.50 \\
\hline C31 & Columbus $\mathrm{OH}$ & 0.00 & 0.00 & 0.00 & 5.00 & 1.00 & 0.00 \\
\hline C32 & Altoona PA & 0.00 & 0.00 & 0.00 & 6.00 & 0.00 & 0.00 \\
\hline C33 & Rapid City SD & 6.00 & 0.00 & 0.50 & 6.00 & 0.00 & 0.50 \\
\hline C34 & Vermillion SD & 6.00 & 1.00 & 1.00 & 6.00 & 1.00 & 1.00 \\
\hline C35 & Chattanooga TN & 7.20 & 1.00 & 0.90 & 7.20 & 0.00 & 0.90 \\
\hline C36 & Knoxville TN & 7.80 & 1.00 & 1.80 & 7.80 & 0.00 & 1.80 \\
\hline C37 & Abilene TX & 0.00 & 0.00 & 0.00 & 7.80 & 0.00 & 0.80 \\
\hline C38 & El Paso TX & 0.00 & 0.00 & 0.00 & 8.30 & 0.00 & 2.80 \\
\hline C39 & Ft. Worth TX & 0.00 & 0.00 & 0.00 & 7.80 & 0.00 & 2.80 \\
\hline $\mathrm{C} 40$ & Houston TX & 0.00 & 0.00 & 0.00 & 8.30 & 2.00 & 1.30 \\
\hline C41 & Lubbock TX & 0.00 & 0.00 & 0.00 & 7.80 & 0.10 & 2.70 \\
\hline $\mathrm{C} 42$ & Salt Lake City UT & 0.00 & 0.00 & 0.00 & 6.30 & 0.10 & 1.70 \\
\hline C43 & Charleston WV & 6.00 & -3.00 & 6.00 & 6.00 & 2.00 & 1.00 \\
\hline C44 & Appleton WI & 0.00 & 0.00 & 0.00 & 5.00 & 1.00 & 0.00 \\
\hline $\mathrm{C} 45$ & Eau Claire WI & 0.00 & 0.00 & 0.00 & 5.00 & 1.00 & 0.00 \\
\hline $\mathrm{C} 46$ & Madison WI & 0.00 & 0.00 & 0.00 & 5.50 & 1.00 & 0.50 \\
\hline $\mathrm{C} 47$ & Oshkosh WI & 0.00 & 0.00 & 0.00 & 5.00 & 1.00 & 0.00 \\
\hline $\mathrm{C} 48$ & Casper WY & 4.00 & 0.00 & 0.00 & 4.00 & 0.00 & 0.00 \\
\hline Mean & & 2.99 & -0.06 & 1.06 & 6.48 & 0.78 & 1.05 \\
\hline Stand & ard Deviation & 3.48 & 1.38 & 2.11 & 134 & 0.82 & 0.90 \\
\hline Minir & num & 0.00 & -4.00 & 0.00 & 4.00 & 0.00 & 0.00 \\
\hline Maxi & num & 9.00 & 3.00 & 7.80 & 9.00 & 3.00 & 3.00 \\
\hline
\end{tabular}


Perishables

$$
Q_{i j, k, t-1}
$$$$
-0.207
$$$$
(0.009)
$$

\section{Regression $1 \quad$ Regression 2}

$-0.273$

$(0.011)$

Non-Perishables

$\begin{array}{lll}Q_{i j, k, t-1} & -0.117 & -0.160 \\ & (0.009) & (0.012)\end{array}$

Services

$\begin{array}{lll}Q_{i j, k, t-1} & -0.012 & -0.051 \\ & (0.010) & (0.012)\end{array}$

Std. error of Regression

.1239

.1229

Number of Observations

Product dummies

21319

21319

no

yes

yes

Notes: Standard errors in parentheses. The regression run was:

$\Delta Q_{i, k, t}=\sum_{n=1}^{3} \beta_{n} Q_{i j, k, t-1}+\sum_{\mathrm{m}-1}^{16} \delta_{m} \Delta Q_{i j, k, t-m}+\mathrm{dummies}+\varepsilon_{i j, k, t}$, where $\mathrm{n}=\mathbf{l}$ if $\mathrm{k}$ is perishable, $\mathbf{n}=2$ if $\mathbf{k}$ is non-perishable, and $\mathbf{n}=3$ if $\mathrm{k}$ is a service, and, $Q_{i j, k, t}$, is defined as the percentage difference in price of commodity $\mathbf{k}$ at time $\mathrm{t}$ between cities $\mathrm{i}$ and $\mathrm{j}$, i.e., $Q_{i j, k, t}=\ln \left(P_{i, k, t} / P_{j, k, t}\right)$. New Orleans is defined as the benchmark city. 


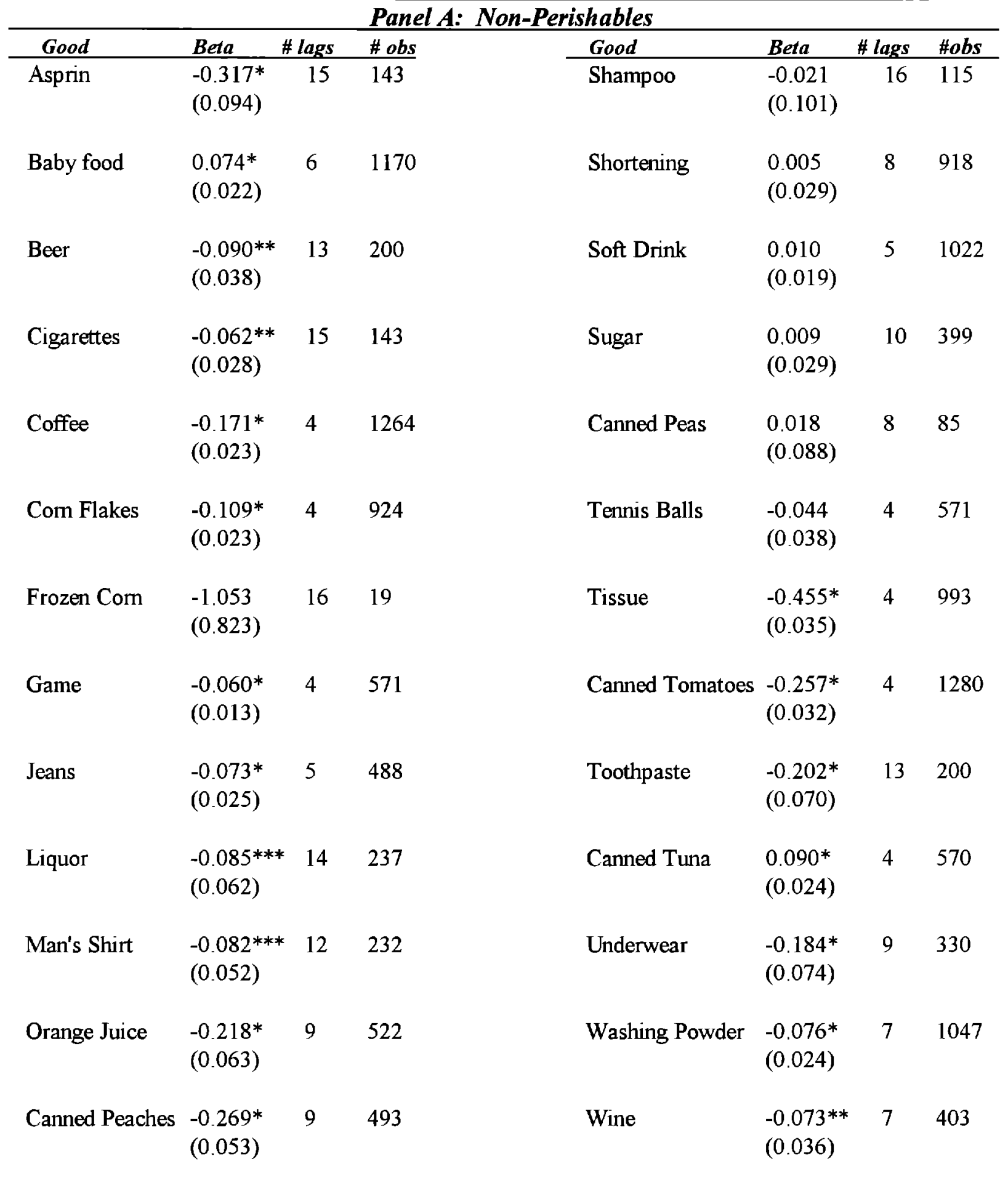

Notes: Standard errors are in parentheses, and '*', '**', '***', denote significant at the 1\%, 5\%, and $10 \%$ levels. For each good, the regression run was:

$\Delta Q_{i j, k, t}=\beta Q_{i j, k, t-1}+\sum_{m=1}^{s(k)} \gamma_{m} \Delta Q_{i j, k, t-m}+\varepsilon_{i j, k, t}$, where, $Q_{i j, k, t}$, is defined as the percentage difference in price of commodity $\mathbf{k}$ at time $\mathrm{t}$ between cities $\mathrm{i}$ and $\mathrm{j}$, i.e., $Q_{i j, k, t}=\ln \left(P_{i, k, t} / P_{j, k, t}\right)$. $s(k)$ is chosen as the highest significant lag from a preliminary regression including 16 lags. The F-Test is a test of the joint significance of city-pair dummies. New York is defined as the benchmark city. 


\begin{tabular}{|c|c|c|c|c|c|c|c|}
\hline Good & Beta & 7 lags & $\# o b s$ & Good & Beta \# I & lags & \#obs \\
\hline \multicolumn{8}{|l|}{ Perishables: } \\
\hline Bacon & $\begin{array}{l}-0.149^{*} \\
(0.023)\end{array}$ & 4 & 1471 & McDonalds & $\begin{array}{l}-0.146^{*} \\
(0.021)\end{array}$ & 4 & 571 \\
\hline Bananas & $\begin{array}{l}-0.296^{*} \\
(0.089)\end{array}$ & 14 & 237 & Pizza & $\begin{array}{l}-0.023^{* * *} \\
(0.016)\end{array}$ & $=12$ & 232 \\
\hline Bread & $\begin{array}{l}-0.191 * \\
(0.022)\end{array}$ & 4 & 1261 & Services: & & & \\
\hline Cheese & $\begin{array}{l}-0.009 \\
(0.035)\end{array}$ & 14 & 171 & Appliance repair & $\begin{array}{l}-0.099 * \\
(0.019)\end{array}$ & 7 & 676 \\
\hline Eggs & $\begin{array}{l}0.041 \\
(0.046)\end{array}$ & 14 & 237 & Auto Maintenance & $\begin{array}{l}-0.081 * \\
(0.020)\end{array}$ & 10 & 396 \\
\hline Ground Beef & $\begin{array}{l}0.060 \\
(0.141)\end{array}$ & 15 & 143 & Beauty Salon & $\begin{array}{l}-0.089 * * \\
(0.041)\end{array}$ & 11 & 264 \\
\hline Lettuce & $\begin{array}{l}-0.261^{*} \\
(0.045)\end{array}$ & 10 & 673 & Bowling & $\begin{array}{l}-0.216^{*} \\
(0.060)\end{array}$ & 15 & 143 \\
\hline Margarine & $\begin{array}{l}0.056 \\
(0.106)\end{array}$ & 16 & 110 & Dentist & $\begin{array}{l}0.100^{*} \\
(0.039)\end{array}$ & 16 & 103 \\
\hline Milk & $\begin{array}{l}-0.100^{* * *} \\
(0.063)\end{array}$ & 16 & 115 & Doctor & $\begin{array}{l}-0.130^{*} \\
(0.047)\end{array}$ & 16 & 111 \\
\hline Potatoes & $\begin{array}{l}-0.161^{*} \\
(0.072)\end{array}$ & 11 & 548 & Dry Cleaning & $\begin{array}{l}-0.152^{*} \\
(0.011)\end{array}$ & 4 & 1507 \\
\hline Steak & $\begin{array}{l}0.001 \\
(0.045)\end{array}$ & 10 & 338 & Hospital Room & $\begin{array}{l}-0.008 \\
(0.009)\end{array}$ & 14 & 237 \\
\hline Whole Chicken & $\begin{array}{l}-0.221^{*} \\
(0.028)\end{array}$ & 4 & 1507 & Man's Haircut & $\begin{array}{l}-0.050^{* * *} \\
(0.037)\end{array}$ & 13 & 327 \\
\hline Fried Chicken & $\begin{array}{l}-0.253^{*} \\
(0.062)\end{array}$ & 13 & 200 & Movie & $\begin{array}{l}-0.039 \\
(0.032)\end{array}$ & 14 & 230 \\
\hline
\end{tabular}

Notes: Standard errors are in parentheses, and '*', ‘**', '***', denote significant at the $1 \%, 5 \%$, and $10 \%$ levels. For each good, the regression run was:

$\Delta Q_{i j, k, t}=\beta Q_{i j, k t-1}+\sum_{m=1}^{s(k)} \gamma_{m} \Delta Q_{i j, k, t-m}+\varepsilon_{i j, k, t}$, where, $Q_{i j, k, t}$, is defined as the percentage difference in price of commodity $\mathrm{k}$ at time $\mathrm{t}$ between cities $\mathrm{i}$ and $\mathrm{j}$, i.e., $Q_{i j, k, t}=\ln \left(P_{i, k, t} / P_{j, k, t}\right) . \quad s(k)$ is chosen as the highest significant lag from a preliminary regression including 16 lags. The F-Test is a test of the joint significance of city-pair dummies. New York is defined as the benchmark city. 


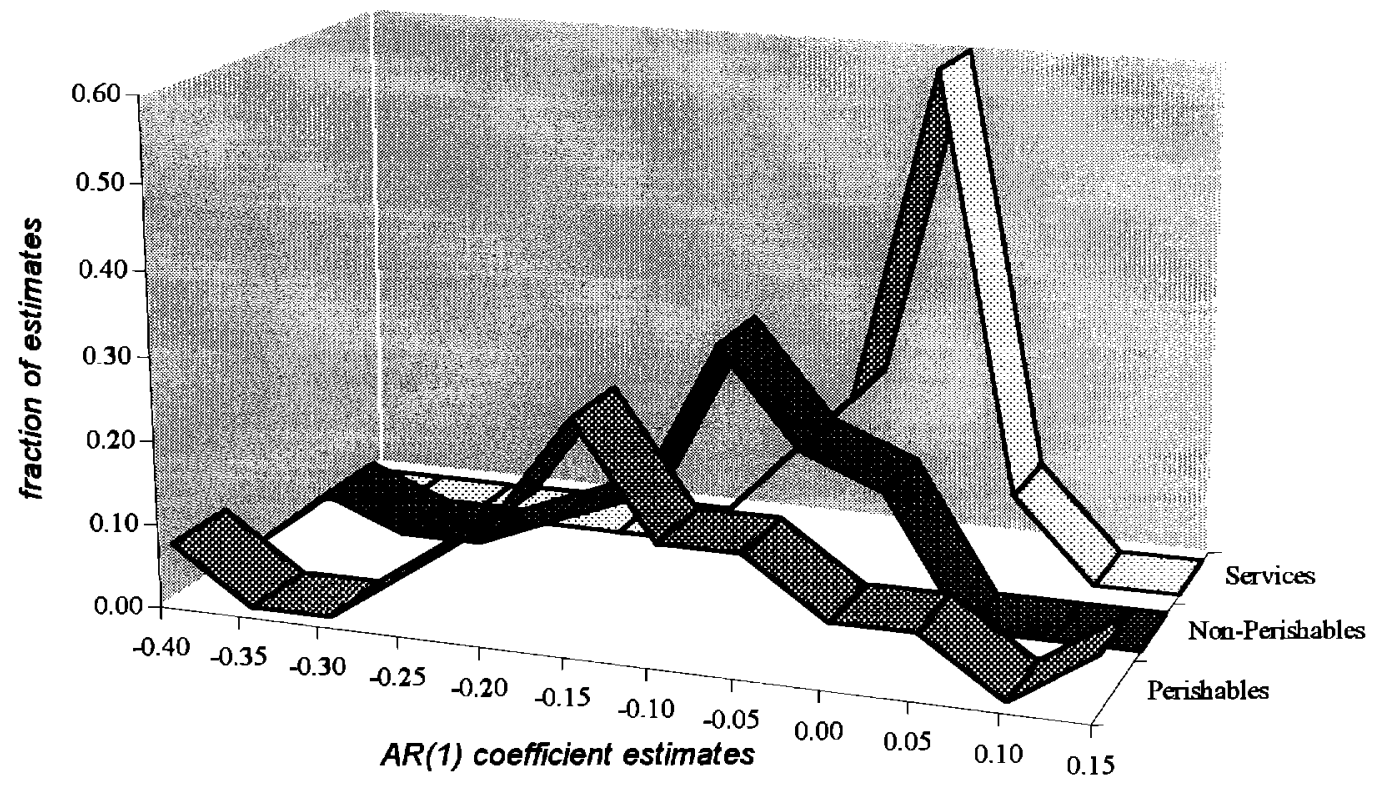

\begin{tabular}{|lccccccccccc|}
\hline & $<-.40$ & $(-.40,-.35)$ & $(-.35,-.30)$ & $(-.30,-.25)$ & $(-.25,-.20)$ & $(-.20,-.15)$ & $(-.15,-.10)$ & $(-.10,-.05)$ & $(-.05,0.0)$ & $>0.0$ \\
Perishables & 0.07 & 0.00 & 0.00 & 0.07 & 0.13 & 0.27 & 0.13 & 0.13 & 0.07 & 0.14 \\
Non-Perishables & 0.00 & 0.08 & 0.04 & 0.04 & 0.08 & 0.12 & 0.31 & 0.19 & 0.15 & 0.00 \\
Services & 0.00 & 0.00 & 0.00 & 0.00 & 0.00 & 0.00 & 0.10 & 0.20 & 0.60 & 0.10 \\
\hline
\end{tabular}

Figure I

Empirical Density Functions of Coefficient Estimates

Based on panel unit root test regressions without city dummies 